\title{
Identification of Fungal Pathogens to Control Postharvest Passion Fruit (Passiflora edulis) Decays and Multi-Omics Comparative Pathway Analysis Reveals Purple Is More Resistant to Pathogens than a Yellow Cultivar
}

\author{
Hafiz Muhammad Rizwan ${ }^{1}$, Lin Zhimin $^{2}{ }^{(D}$, Wiwiek Harsonowati ${ }^{3} \mathbb{D}$, Abdul Waheed $^{4}$, Yang Qiang ${ }^{1}$,

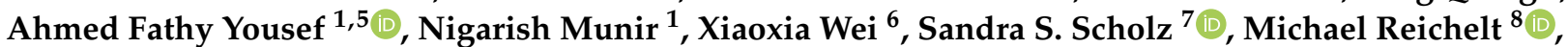
Ralf Oelmüller ${ }^{1,7}$ and Faxing Chen ${ }^{1, * \mathbb{D}}$

check for updates

Citation: Rizwan, H.M.; Zhimin, L.; Harsonowati, W.; Waheed, A.; Qiang, Y.; Yousef, A.F.; Munir, N.; Wei, X.; Scholz, S.S.; Reichelt, M.; et al. Identification of Fungal Pathogens to Control Postharvest Passion Fruit (Passiflora edulis) Decays and Multi-Omics Comparative Pathway Analysis Reveals Purple Is More Resistant to Pathogens than a Yellow Cultivar. J. Fungi 2021, 7, 879. https://doi.org/10.3390/jof7100879

Academic Editor: Paloma Melgarejo

Received: 23 September 2021

Accepted: 15 October 2021

Published: 19 October 2021

Publisher's Note: MDPI stays neutra with regard to jurisdictional claims in published maps and institutional affiliations.

Copyright: (c) 2021 by the authors. Licensee MDPI, Basel, Switzerland. This article is an open access article distributed under the terms and conditions of the Creative Commons Attribution (CC BY) license (https:// creativecommons.org/licenses/by/ $4.0 /)$.
1 College of Horticulture, Fujian Agriculture and Forestry University, Fuzhou 350002, China; chrizwan51@gmail.com (H.M.R.); 1200305020@fafu.edu.cn (Y.Q.); Ahmedfathy201161@yahoo.com (A.F.Y.); nigarish.munir@yahoo.com (N.M.); ralf.oelmueller@uni-jena.de (R.O.)

2 Institute of Biotechnology, Fujian Academy of Agricultural Sciences, Fuzhou 350002, China; lzm@fjage.org

3 Department of Bioresource Science, College of Agriculture, Ibaraki University, 3-21-1 Chuuo, Ami, Inashiki 300-0393, Japan; w_harsonowati@yahoo.com

4 Key Laboratory for Bio Pesticide and Chemical Biology, Ministry of Education, Fujian Agriculture and Forestry University, Fuzhou 350002, China; Waheed90539@gmail.com

5 Department of Horticulture, College of Agriculture, University of Al-Azhar (Branch Assiut), Assiut 71524, Egypt

6 Fruit Research Institute, Fujian Academy of Agricultural Sciences, Fuzhou 350002, China; zhw7782352@sina.com

7 Matthias Schleiden Institute, Plant Physiology, Friedrich-Schiller-University Jena, Dornburger Str. 159, 07743 Jena, Germany; s.scholz@uni-jena.de

8 Department of Biochemistry, Max Planck Institute for Chemical Ecology, Hans-Knöll-Str. 8, 07745 Jena, Germany; reichelt@ice.mpg.de

* Correspondence: fxchen@fafu.edu.cn

Abstract: Production of passion fruit (Passiflora edulis) is restricted by postharvest decay, which limits the storage period. We isolated, identified, and characterized fungal pathogens causing decay in two passion fruit cultivars during two fruit seasons in China. Morphological characteristics and nucleotide sequences of ITS-rDNA regions identified eighteen isolates, which were pathogenic on yellow and purple fruit. Fusarium kyushuense, Fusarium concentricum, Colletotrichum truncatum, and Alternaria alternata were the most aggressive species. Visible inspections and comparative analysis of the disease incidences demonstrated that wounded and non-wounded yellow fruit were more susceptible to the pathogens than the purple fruit. Purple cultivar showed higher expression levels of defense-related genes through expression and metabolic profiling, as well as significantly higher levels of their biosynthesis pathways. We also found fungi with potential beneficial features for the quality of fruits. Our transcriptomic and metabolomics data provide a basis to identify potential targets to improve the pathogen resistance of the susceptible yellow cultivar. The identified fungi and affected features of the fruit of both cultivars provide important information for the control of pathogens in passion fruit industry and postharvest storage.

Keywords: disease management; ITS-rDNA sequence; metabolic profiling; pathogenic fungi; transcriptomics

\section{Introduction}

Passion fruit (Passiflora edulis) belongs to the Passifloraceae family and is a perennial evergreen climbing vine with more than 500 species. The plant is widely cultivated throughout tropical and subtropical regions of the world. Brazil is one of the largest producers 
of passion fruit [1]. From the estimated 1.46 million tons of global production in 2017, 1 million tons came from Brazil [2]. Passion fruit is usually consumed as fruit juice; it is rich in nutrients with pleasing and diverse aromas, and the fresh fruit is used as raw material in the beverage industry [3]. The passion fruit is also rich in flavonoids, alkaloids, and other bioactive compounds used for traditional medicines in several countries, such as flowers for bronchitis and cough, leaf extracts for insomnia, anxiety, and alcoholism, and seed oil for oil massages and as a lubricant [4]. Recently, two cultivars, the acidic purple passion fruit (P. edulis cv. Sims) and the sweeter yellow passion fruit (P. edulis cv. flavicarpa), have become important commercial fruit and are growing at a large scale in different provinces of China, especially in Guangdong, Fujian, Yunnan, Guangxi, and Taiwan [5]. The passion fruit industry and market are constantly evolving worldwide due to the increasing demand of the active ingredients in the fruit and the health benefits for consumers.

Although many factors affect the fruit quality, such as the selection of the variety, the cultivation system, climatic conditions, harvesting procedures and times [6], the market suffers most under the rapid decomposition of the harvested fruit, which cannot be stored for longer periods at room temperatures. The enormous postharvest losses between harvest and consumption are caused by the high susceptibility of the fruit to pathogen infections, which can only be counteracted by careful handling, packaging, and transportation, e.g., at lower temperatures [7]. In particular, physical damage, softening, water loss, and shriveling lead to fruit decay and deterioration, which results in huge economic loss [8]. According to the Food and Agriculture Organization (FAO), the global average loss due to food postharvest losses are about $29 \%$ in highly developed countries and about $38 \%$ in developed Asian, African, Latin American, and Southeast Asian countries [9], and these losses are even higher for horticultural crops and exotic fruit [10]. Microbial infections are the main cause for postharvest losses worldwide and the major post-harvest diseases are green and blue mold caused by Penicillium digitatum and P. italicum [11], brown rot by Monilinia fructicola, Alternaria black spot by Alternaria alternata, Rhizopus rot by Rhizopus stolonifer [12], and anthracnose by Colletotrichum brevisporum, C. boninense, and C. brevisporum [13].

Previous reports from different countries identified different pathogens that cause postharvest passion fruit decay, such as C. brevisporum in China and Japan [14,15], C. gloeosporioides in Brazil [16], Lasiodiplodia theobromae in China [17], and Fusarium semitectum in Brazil [18], as well as Phytophthora nicotianae var. parasitica, P. drechsleri, and C. gloeosporioides sensu lato in Colombia [19]. These findings suggest that the pathogens that caused decay could be differ in different areas of the world. Molecular identification of fungal pathogens usually relies on sequencing the nuclear ribosomal internal transcribed spacer (ITS) region [20-24], which is often complemented by morphological and physiological studies. Since passion fruit has become commercially important in China, the industry searches intensively for tools to restrict postharvest decay. An important aspect in this scenario is the identification of the fungal pathogen species that cause the disease. Therefore, the first objectives were (i) the isolation, identification, and morphological characterization of the pathogenic and non-pathogenic fungal species associated with the postharvest passion fruit decay; (ii) the characterization of the pathogenicity of the fungal pathogens, which are living on the fruit of the yellow and purple cultivars; and (iii) the confirmation of the identified pathogens through molecular analysis. Summed up, our findings showed that the identified pathogens propagate faster on the fruit of the yellow cultivar. Therefore, we performed a multi-omics approach with the peels of the yellow and purple fruit to understand why the purple fruit are more resistant to infections with those pathogens, which were found on both types of fruits.

\section{Materials and Methods}

\subsection{Fruit Sample Collection}

The experiments were carried out during 2019-2020 at the Institute of Subtropical Fruit, Fujian Agriculture and Forestry University, China. The infected fruits (thirty fruits from each cultivar with three replications) of the commercial passion fruit cultivars, yellow 
(P. edulis. Flavicarpa cv Huangjin) and purple (P. edulis. Sims cv Tainong), were collected from private orchards located in Fujian province, China $\left(23^{\circ} 48^{\prime} 35.2^{\prime \prime} \mathrm{N}\right.$ and $\left.117^{\circ} 07^{\prime} 08.1^{\prime \prime} \mathrm{E}\right)$. Thereafter, fruit were moist incubated at room temperature $\left(25 \pm 2{ }^{\circ} \mathrm{C}\right)$ for 2 weeks by placing them in plastic containers, covered with lids and moist towel paper to maintain the relative humidity ( $\mathrm{RH}$ ) for pathogen growth and development. The collected fruits showed decay symptoms within 2 weeks.

\subsection{Fungal Pathogens Isolation}

The infected tissues were cut into 3-5 $\mathrm{mm}$ pieces from the symptomatic fruit and surface-sterilized by immersion in $75 \%(v / v)$ ethanol for $30 \mathrm{~s}$, followed by $1 \%$ sodium hypochlorite $(\mathrm{NaClO})$ for $3 \mathrm{~min}$, rinsed 3 times with sterile distilled water, and dried on sterilized tissue paper. The surface-sterilized tissues were then cultured on $90 \mathrm{~mm}$ Petri dishes containing potato dextrose agar (PDA) medium (38 g PDA in $1 \mathrm{~L}$ distilled water) amended with $100 \mathrm{mg} \mathrm{L}^{-1}$ ampicillin to prevent bacterial contamination, and incubated for $12 \mathrm{~h}$ photoperiods at $25 \pm 2{ }^{\circ} \mathrm{C}$ for $5-7 \mathrm{~d}$. Emerging colonies were then transferred many times to fresh PDA plates by the hyphal tip method until pure cultures were obtained. Pure cultures were further grown on PDA medium at $25 \pm 2{ }^{\circ} \mathrm{C}$ for morphological characterization, DNA extraction, and pathogenicity tests. All isolates were maintained and stored in $20 \%$ glycerol at $-80{ }^{\circ} \mathrm{C}$ until use.

\subsection{Morphological Identification of Fungal Isolates}

The morphology of fungal isolates was studied macroscopically by observing the colony features (shape, color, size). For the microscopic study, the fungi were grown on PDA medium at $25 \pm 2{ }^{\circ} \mathrm{C}$ for 7-10 d. Small PDA pieces $(2 \times 2 \times 2 \mathrm{~mm})$ were sandwiched between two $18 \times 18 \mathrm{~mm}$ cover glasses and placed on water agar plates to provide humidity. A small spore fragment was taken from the fresh sprouting culture by sterilized needle and distributed on the edge of the surface of the small PDA pieces, before incubation at $25 \pm 2{ }^{\circ} \mathrm{C}$ for 2 weeks. The glass covers were carefully mounted on $76 \times 26 \mathrm{~mm}$ micro glass slides after sufficient growth of the cultures. The conidia were observed under an optical microscope with a digital camera at 40× magnification (Phenix, BMC300, Jiangxi, China).

\subsection{Molecular Identification of Fungal Isolates}

Fungal isolates were grown on PDA medium at $25 \pm 2{ }^{\circ} \mathrm{C}$ for 2 weeks, to confirm the morphological features. The fresh mycelia from each isolate were scraped directly from the plates with sterilized glass slides and transferred to $1.5 \mathrm{~mL}$ Eppendorf tubes for genomic DNA extraction using the PREPMAN Ultra Sample Preparation Reagent (Cat\# 4318930, ThermoFisher, Applied Biosystems ${ }^{\mathrm{TM}}$, Warrington, UK) according to the manufacturer's protocol. The partial 18S small subunit (SSU), internal transcribed spacer (ITS) 1-5.8 S-ITS2 region, and partial 28S large subunit (LSU) were amplified from the genomic DNA by polymerase chain reaction (PCR) with universal primers ITS1F: $5^{\prime}$ CTTGGTCATTTAGAGGA AGTAA-3' and ITS4-R: 5'-TCCTCCGCTTATTGAT ATGC-3', respectively [25]. PCR amplification was conducted in a $50 \mu \mathrm{L}$ reaction volume containing $2 \mu \mathrm{L}$ genomic DNA (100 ng), $2.5 \mu \mathrm{L}$ of each primer $(100 \mu \mathrm{M}), 25 \mu \mathrm{L}$ of 2 Hieff Canace ${ }^{\circledR}$ Gold PCR Master Mix (Cat\# 10149ES08, Yeasen Bio, Shanghai, China), and sterilized Milli-Q water. PCR was carried out by using a T100 ${ }^{\mathrm{TM}}$ Thermal Cycler (Bio-Rad, Singapore) with the following conditions: $94^{\circ} \mathrm{C}$ for $4 \mathrm{~min}$; followed by 35 cycles for $30 \mathrm{~s}$ at $94{ }^{\circ} \mathrm{C} ; 55 \mathrm{~s}$ annealing at $52{ }^{\circ} \mathrm{C}, 2 \mathrm{~min}$ at $72{ }^{\circ} \mathrm{C}$; and a final extension for $10 \mathrm{~min}$ at $72{ }^{\circ} \mathrm{C}$; holding at $12{ }^{\circ} \mathrm{C}$. The PCR products were analyzed by running the sample on a $1.5 \%$ agarose gel in $1 \times \mathrm{TAE}$ (Tris-acetate-EDTA) buffer and bands were visualized in UV transilluminator (Peiqing, Model: JS-680D, shanghai, China). The PCR products were purified using SanPrep Column PCR Product Purification Kit No: B518141 and were custom sequenced at Sangon Biotech (Sangon Bio, shanghai, China). The obtained sequences were assembled to contig by using ChromasPro software 2.1.8 (Technelysium Pty Ltd., Brisbane, Australia). The obtained sequences were compared using the National Center for Biotechnology Information (NCBI) 
online nucleotide basic local alignment search tool (BLAST) database for closely related taxa (http:/ / www.ncbi.nlm.nih.gov/blast/ accessed on 5 August 2020). A name was allotted to the selected isolate, when the BLAST hits were $\geq 98 \%$ for the top three matchings with the same species [22]. GenBank sequences were submitted to NCBI GenBank database under accession numbers MW880893-MW880918.

\subsection{Phylogenetic Analysis}

For phylogenetic analysis, the sequence data obtained for the 26 isolates were used for sequence similarity search in the GenBank (Table S1), and the results edited with the MEGA-X software 10.1.8. The neighbor-joining method was used to infer the evolutionary relationship of the fugal isolates in this phylogenetic tree and bootstrapped through 1000 replications to determine the percentage among clades.

\subsection{Pathogenicity Test}

The 26 isolates from 12 morphotypes identified in this study were tested on the healthy yellow (P. edulis. Flavicarpa cv Huangjin) and purple (P. edulis Sims cv Tainong) passion fruit cultivars for their pathogenicity by two ways. (i) Wounded fruit were infected with $1 \mathrm{~mL}$ of a $1 \times 10^{6}$ conidia $\mathrm{mL}^{-1}$ suspension, and (ii) non-wounded intact fruit by using 5-mm mycelial plugs. Spore suspensions were prepared by incubating the isolates on PDA media at $25 \pm 2{ }^{\circ} \mathrm{C}$, in light-dark $(18-6 \mathrm{~h})$ cycles for $7-10 \mathrm{~d}$. The inoculum was prepared by flooding the cultures with $10 \mathrm{~mL}$ distilled water and the surface was slightly scraped with sterilized cell spreader before the conidial suspensions were sieved by using double layers of muslin cloth. The conidial concentration was examined and adjusted to $1 \times 10^{6}$ conidia $\mathrm{mL}^{-1}$ by using a hemocytometer. Fruit were washed with tap water, surface sterilized by soaking in $75 \%(v / v)$ ethanol for $30 \mathrm{~s}$, followed by $2 \% \mathrm{NaClO}$ solution for $3 \mathrm{~min}$, rinsed 3 times with sterile distilled water, and air-dried for approximately $30 \mathrm{~min}$ in a laminar flow chamber. All fruit were wounded with a sterile needle about $3 \mathrm{~mm}$ depth in the equatorial zone and $10 \mu \mathrm{L}$ conidial suspensions $\left(1 \times 10^{6}\right.$ conidia $\left.\mathrm{mL}^{-1}\right)$ were pipetted on the wounded spots, while control fruit were treated with sterilized distilled water. Mycelia plugs around $5 \mathrm{~mm}$ in diameter from each isolate were inoculated on the equatorial zone with PDA plug as control for non-wounded fruits. The inoculated fruit were moist incubated by placing them into plastic containers on wet paper at $25 \pm 2{ }^{\circ} \mathrm{C}$, light-dark (18-6 h) cycle and 80\% RH. Three wounded and three non-wounded fruit were inoculated per cultivar for each isolate and the experiment was repeated twice. Fruits were observed and photographed on the 4 th, 8 th, and 12th day post-inoculation (dpi) to record the disease incidence and the lesion diameter. After $12 \mathrm{dpi}$, the fruit were cut through the center of lesions to observe the symptoms and lesions. The fungi were re-isolated from the resulted lesion margins of the inoculated fruit and cultured on fresh PDA plates, and then re-identified by comparing their morphological and microscopic features with those of the original isolates.

\subsection{Phytohormones Analysis}

Phytohormones were extracted from the peels of the fruit of the yellow and purple passion fruit cultivars. Frozen samples were homogenized for $30 \mathrm{~s}$ at 1000 strokes per minute in a 2010 Geno/Grinder ${ }^{\circledR}$ (SPEX SamplePrep, Stanmore, UK) and mixed with $1 \mathrm{~mL}$ methanol containing $40 \mu \mathrm{g} / \mathrm{L}^{-1}$ of $\mathrm{D}_{6}$-JA (HPC Standards $\mathrm{GmbH}$, Cunnersdorf, Germany), $\mathrm{D}_{6}$-ABA (Toronto Research Chemicals, Toronto, Canada), D4-SA (Santa Cruz Biotechnology, TX, U.S.A) and $8 \mu \mathrm{g} \mathrm{L}^{-1}$ of $\mathrm{D}_{6}$-JA-Ile (HPC Standards $\mathrm{GmbH}, \mathrm{Cunnersdorf,} \mathrm{Germany).} \mathrm{All}$ samples were shaken for $30 \mathrm{~min}$ at $4{ }^{\circ} \mathrm{C}$ and centrifuged at $17,900 \times \mathrm{g}$ for $20 \mathrm{~min}$ at $4{ }^{\circ} \mathrm{C}$. The supernatants were collected and the sample re-extracted with $500 \mu \mathrm{L}$ methanol. The combined supernatants were evaporated to dryness at $30^{\circ} \mathrm{C}$ using a vacuum concentrator (Eppendorf, Wesseling, Germany). Residues were re-suspended in $200 \mu \mathrm{L}$ methanol and centrifuged at $17,900 \times g$ for $10 \mathrm{~min}$. The supernatants were collected and measured with the QTRAT6500 LC-MS/MS system (AB Sciex, Darmstadt, Germany) as previously 
described. Since it was observed that both the $\mathrm{D}_{6}$-labeled JA and JA-Ile contained $40 \%$ of the corresponding $\mathrm{D}_{5}$-labeled compounds, both peaks were combined for analysis.

\subsection{RNA Extraction, cDNA Library Construction, and Transcriptome Sequencing}

Total RNA was extracted and purified from yellow and purple fruit peel samples following the manufacturer's instructions using Tiangen Kits (Tiangen, China). The RNA quality was examined by using agarose gel electrophoresis (1\%) and 2100 Bioanalyzer (Agilent Technologies, CA, USA). The sequencing libraries were generated using a NEBNext ${ }^{\circledR}$ Ultra $^{\mathrm{TM}}$ RNA Library Prep Kit for Illumina ${ }^{\circledR}$ (NEB, Boston, MA, USA) following the manufacturer's instructions. In order to select cDNA fragments of preferentially $240 \mathrm{bp}$ in length, the library fragments were purified with AMPure XP system (Beckman Coulter, Beverly, MA, USA). The clustering of the index-coded samples was performed on a cBot Cluster Generation System using TruSeq PE Cluster Kit v3-cBot-HS (Illumina, San Diego, CA, USA) according to the manufacturer's recommendation. After cluster generation, the library preparations were sequenced on an Illumina HiSeq 2000 platform and paired-end reads were generated (Biomarker, Technologies Corporation, Bejing, China). FASTQ format was used to store raw reads. The high quality reads (clean reads) were obtained by removing the low-quality reads, reads containing ploy- $\mathrm{N}$ and adapter sequences from the raw reads processed through in-house Perl scripts. At the same time, Q20, Q30, GC-content and sequence duplication level of the clean data were calculated. Trinity version 2.5.1 was used to assemble the transcriptome using the left.fq and right.fq files, with the min kmer cov parameter set as 2 by default and all the other parameters specified as defaults.

\subsection{Gene Function Annotation, Expression, and Pathway Analysis}

The assembled Unigenes sequences were BLASTed in NCBI non-redundant protein sequences (NR); Protein family (Pfam); Clusters of Orthologous Groups of proteins (KOG/COG/eggNOG); Swiss-Prot (a manually annotated and reviewed protein sequence database); Kyoto Encyclopedia of Genes and Genomes (KEGG); and Gene Ontology (GO) databases using BLAST version 2.2.31. The predicted UniGene amino acid sequences were compared with the Pfam database using HMMER software version 2.2.31, to obtain the annotation information. Gene expression level of all the samples were estimated by mapping the clean reads to the Trinity transcripts assembly, using bowtie 2 combined with RSEM version 1.2.1. The read count for each gene was obtained from the mapping results. The FPKM (Fragments Per Kilobase of transcript per Million) value was used to indicate the expression abundance. Prior to differential gene expression analysis for each sequenced library, the read counts were adjusted by EBSeq program package through empirical Bayesian approach. Differential expression analysis of two samples was performed using the EBSeq $\mathrm{R}$ package. $p$-value was adjusted using $q$-value $<0.005$ and $\mid \log _{2}$ (fold change) $\mid>1$ was set as the threshold for significantly differential expression. GO enrichment analysis of the differentially expressed genes (DEGs) was identified by comparing the reads of the purple with the yellow cultivar and was implemented by the topGO $R$ packages version 2.28.0 based on the Kolmogorov-Smirnov test. KEGG enrichment analysis was performed using KOBAS version 2.0.12. After identifying the putative defense-related candidate genes, the respective pathways were analyzed using the KEGG Mapper tool of the Kyoto Encyclopedia of Genes and Genomes (https://www.genome.jp/kegg/tool/map_pathway2.html accessed on 15 May 2021).

\subsection{Non-Target Metabolite Analysis by LC-ESI-Q-ToF-MS}

For the metabolite profiles, the fruit from the purple and yellow cultivars were harvested, the peels were separated from the fruit, frozen in liquid nitrogen, ground with a mortar and pestle and lyophilized. The obtained powder was used for LC-ESI-Q-ToF-MS analyses. A total of $10 \mathrm{mg}$ of ground peel samples was extracted with $1 \mathrm{~mL}$ methanol (from three independent fruit harvests each). For non-target analysis, ultra-high-performance liquid chromatography-electrospray ionization-high resolution mass spectrometry (UHPLC- 
ESI-HRMS) was performed with a Dionex Ultimate 3000 series UHPLC (Thermo Fisher Scientific, Waltham, MA, USA) and a Bruker timsToF mass spectrometer (Bruker Daltonics, Bremen, Germany). UHPLC was used applying a Zorbax Eclipse XDB-C18 column $(100 \mathrm{~mm} \times 2.1 \mathrm{~mm}, 1.8 \mu \mathrm{m}$, Agilent Technologies, Waldbronn, Germany) with a solvent system of $0.1 \%$ formic acid (A) and acetonitrile (B) at a flow rate of $0.3 \mathrm{~mL} \mathrm{~min}^{-1}$. The elution profile was the following: 0 to $0.5 \mathrm{~min}, 5 \% \mathrm{~B} ; 0.5$ to $11.0 \mathrm{~min}, 5 \%$ to $60 \% \mathrm{~B}$ in $\mathrm{A}$; 11.0 to $11.1 \mathrm{~min}, 60 \%$ to $100 \% \mathrm{~B}, 11.1$ to $12.0 \mathrm{~min}, 100 \% \mathrm{~B}$ and 12.1 to $15.0 \mathrm{~min} 5 \%$ B. Electrospray ionization (ESI) in negative/positive ionization mode was used for the coupling of LC to MS. The mass spectrometer parameters were set as follows: capillary voltage $4.5 \mathrm{KV} / 3.5 \mathrm{KV}$, end plate offset of $500 \mathrm{~V}$, nebulizer pressure $2.8 \mathrm{bar}$, nitrogen at $280^{\circ} \mathrm{C}$ at a flow rate of $8 \mathrm{~L} \mathrm{~min}^{-1}$ as drying gas. Acquisition was achieved at $12 \mathrm{~Hz}$ with a mass range from $\mathrm{m} / \mathrm{z} 50$ to 1500 . At the beginning of each chromatographic analysis, $10 \mu \mathrm{L}$ of a sodium formate-isopropanol solution [10 mM solution of $\mathrm{NaOH}$ in 50/50 $(v / v \%)$ isopropanol water containing $0.2 \%$ formic acid] was injected into the dead volume of the sample injection for recalibration of the mass spectrometer using the expected cluster ion $\mathrm{m} / \mathrm{z}$ values.

Data processing: the LC-Q-ToF-MS raw data were recalibrated and then processed with MetaboScape software (Bruker Daltonik GmbH, Bremen, Germany). Automated peak picking and alignment were done within a retention time between 0.4 and $11 \mathrm{~min}$, intensity threshold 500, and minimum occurrence in three out of six samples. Feature intensities were normalized by the fresh weight of the plant material used for extraction. Missing values were replaced by 20 . Feature groups, potentially representing single metabolites, were reduced to one bucket by the MetaboScape software to represent the respective metabolite in later analysis. The following commercial standards were used to verify the identity of the identified compounds by match of retention time and mass spectrum: D-(+)-Glucose (Sigma-Aldrich), D-(+)-Sucrose (Sigma-Aldrich), L-glutamic acid (SigmaAldrich), L-proline (Duchefa), DL-malic acid (Sigma-Aldrich), citric acid (Carl Roth), glutathione reduced form (Sigma-Aldrich), L-tyrosine (Duchefa), adenosine (Sigma-Aldrich), L-phenylalanine (Duchefa), L-glutamine (Sigma-Aldrich), L-(+)-ascorbic acid (Carl Roth), adenosine (Sigma-Aldrich), cyanidin-3-O-glucoside (TransMIT, Gießen, Germany), epicatechin (Sigma-Aldrich), catechin (Sigma-Aldrich), gallocatechin (Cayman Chemical). Citrusin A/hyuganoside III and prunasin were tentatively identified by comparison to literature data [26] (compound numbers 13, 14, and 3 in this reference), and prunasin-rhamnoside according to Farag, Otify [27] (compound number 10 in this reference).

\subsection{Statistical Analysis}

All statistical analyses were performed using SPSS version 19.0 (SPSS, IBM, Armonk, NY, USA) and one-way analysis of variance (ANOVA) was applied to the lesion data of the infected passion fruit from each pathogen. The differences were determined by using Tukey's test and were considered statistically significant if $p<0.05$.

\section{Results}

\subsection{Postharvest Decay Symptoms in Passion Fruits}

Soft and dry visible decay symptoms were observed on the surface of passion fruit within 2 weeks of storage at $25 \pm 2{ }^{\circ} \mathrm{C}$. The $30-40 \%$ visible soft-decay lesions were observed on the fruit surface and characterized by a white to yellowish-light brown skin color, which expand to the whole fruit surface making a soggy fruit (Figure 1A,D). The $10-20 \%$ visible dry decay lesions were observed on fruit surface and characterized by gray to brownishblack with irregular sunken cavities, which expand to the whole fruit surface under suitable environmental conditions (Figure 1B,E). When the decay fruit were cross sectioned, the affected peels and fleshes seemed softer, disorganized, water-saturated, and darker in color (Figure 1C,F). 

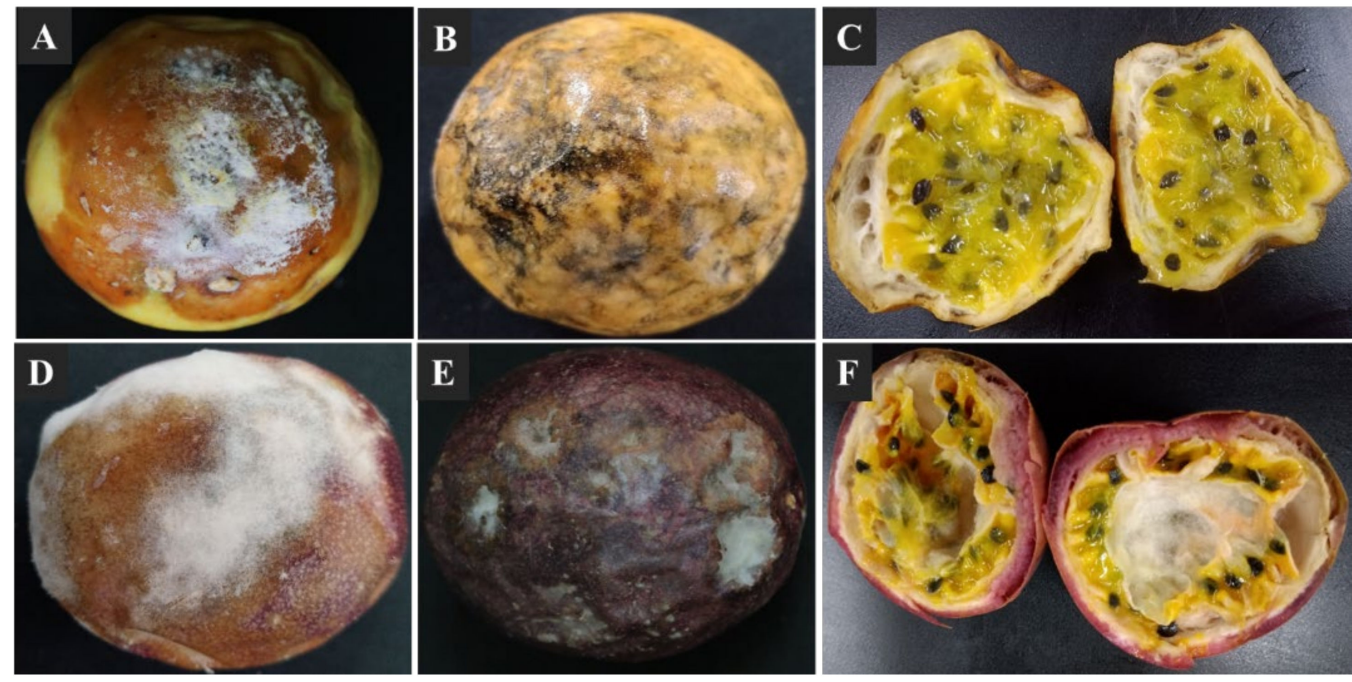

Figure 1. Postharvest decay symptoms on yellow and purple passion fruit; (A,D) visible soft decay symptoms causing soggy fruit; (B,E) visible dry and irregular decay symptoms; (C,F) cross-sections of decayed passion fruit.

\subsection{Fungus Isolates from Infected Passion Fruit}

A total of 26 fungal isolates (13 from yellow and 13 from purple passion fruit) were collected and purified from the infected passion fruit (Figure S1). The isolates from yellow passion fruit were named YPF-1 toYPF-13 and those from the purple passion fruit PPF-1 to PPF-13. Based on morphological inspections and growth parameters, the 26 isolates were initially categorized into 12 different morphotypes (Figure 2, Table 1), which later confirmed by internal transcribed spacer regions (ITS) sequencing. Based on ITS sequencing, 6 of the 26 isolates were obtained only once (= 6 morphotypes), 1 isolate was obtained twice, four or five times, respectively ( $=3$ morphotypes), and 3 isolates were obtained three times ( $=3$ morphotypes, Table 1$)$. A morphotype contains isolates from only one or both cultivars. Interestingly, morphotypes 3, 6, 8, 9, 10, and 12 were only found on the yellow and morphotypes 4 and 11 on the purple cultivar. The isolates belong to different fungal species (spp.), 26.9\% (7/26) Fusarium spp., 19.23\% (5/26) Alternaria spp., 19.23\% (5/26) Aspergillus spp., 15.38\% (4/26) Cladosporium spp., 7.69\% (2/26) Colletotrichum spp., 7.69\% (2/26) Penicillium spp. and 3.85\% (1/26) Microdochium spp. (Figure 2, Table 1).

\subsection{Morphological Characterization of the 12 Morphotypes}

The morphology of the 12 different types of fungi on PDA agar plates, the structure of the hyphae and mycelia as well as of the conidia are shown in Figure 2. A summary of all observations for each of the type of fungi is given in Table 2. Based on their growth rates, the form and color of the upper and lower sides of the colonies on PDA plates, the microscopic structure of the hyphae and mycelial organization, as well as the shape and morphological features of the conidia, we allocated the 12 different morphotypes to the following fungal species: Fusarium kyushuense (type-1), F. concentricum (type-2), Colletotrichum truncatum (type-3), Alternaria alternata (type-4), Cladosporium tenuissimum (type-5), F. equiseti (type-6), Aspergillus aculeatus (type-7), A. europaeus (type-8), A. flavus (type-9), Penicillium chermesinum (type-10), P. paxilli (type-11) and Microdochium phragmitis (type-12). Each allocation is based on comparison of the obtained lab information with literature data. 
Table 1. Categorization of 26 isolates into 12 morphotypes based on morphological and ITS.

\begin{tabular}{cccc}
\hline Morphotype & Number of Isolates & Passion Fruit Cultivar & Identified Species \\
\hline 1 & 3 & yellow and purple & Fusarium kyushuense \\
\hline 2 & 3 & yellow and purple & Fusarium concentricum \\
\hline 3 & 2 & yellow & Colletotrichum truncatum \\
\hline 4 & 5 & purple & Alternaria alternata \\
\hline 5 & 4 & yellow and purple & Cladosporium tenuissimum \\
\hline 6 & 1 & yellow & Fusarium equiseti \\
\hline 7 & 3 & yellow and purple & Aspergillus aculeatus \\
\hline 8 & 1 & yellow & Aspergillus europaeus \\
\hline 9 & 1 & yellow & Aspergillus flavus \\
\hline 10 & 1 & yellow & Penicillium chermesinum \\
\hline 11 & 1 & purple & Penicillium paxilli \\
\hline 12 & 1 & yellow & Microdochium phragmitis \\
\hline
\end{tabular}
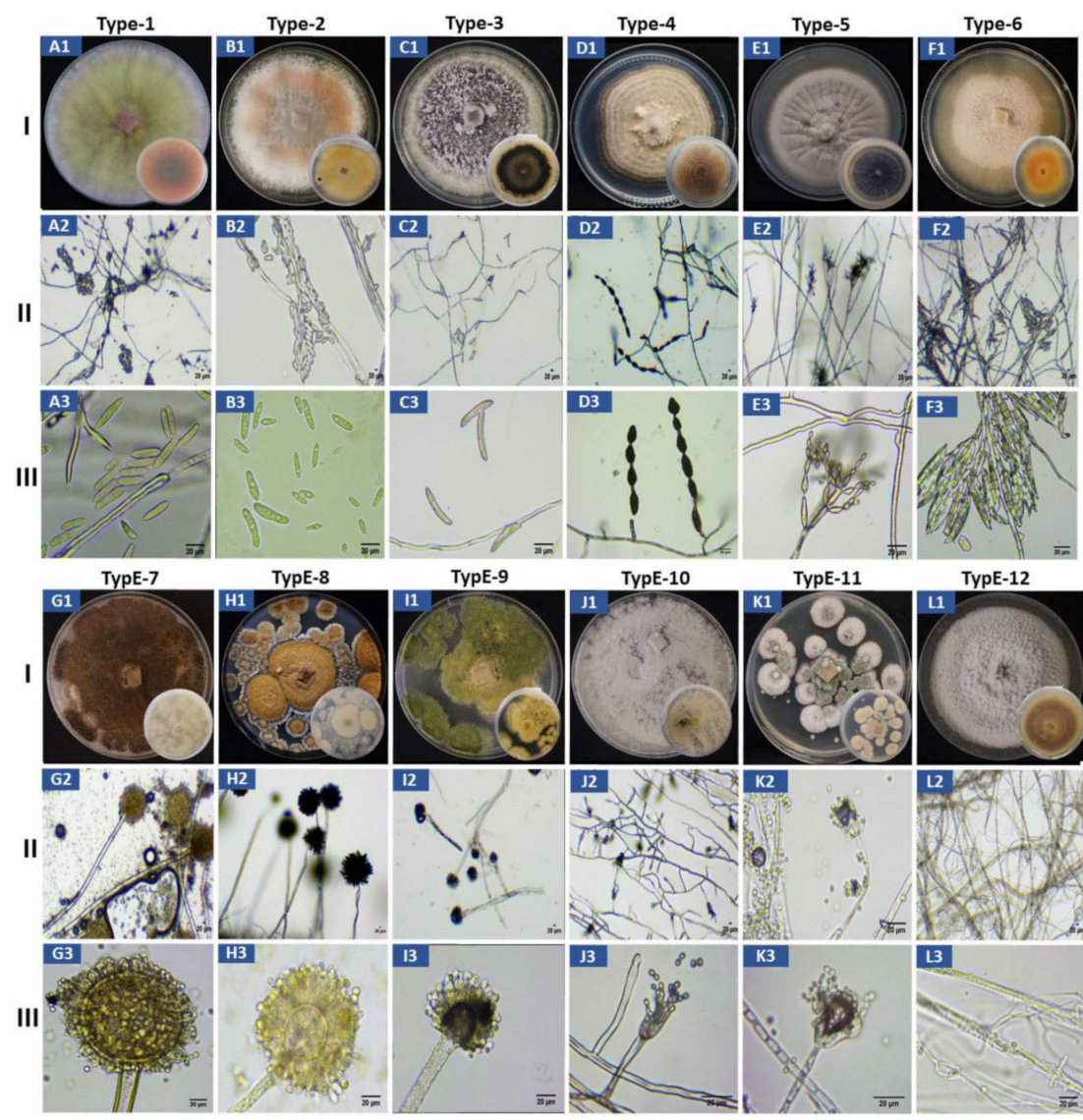

Figure 2. Morphological characterization of passion fruit isolates type-1 to type-12; I (A1-L1) colony morphology on PDA media, II (A2-L2) thread like structure showing hyphae and mycelium and III (A3-L3) conidia. Type-1 (A1-A3) = Fusarium kyushuense; type-2 (B1-B3) = Fusarium concentricum; type-3 (C1-C3) = Colletotrichum truncatum; type-4 (D1-D3) = Alternaria alternata type-5 $($ E1-E3) = Cladosporium tenuissimum; type-6 (F1-F3) = Fusarium equiseti; type-7 (G1-G3) = Aspergillus aculeatus; type-8 (H1-H3) = Aspergillus europaeus; type-9 (I1-I3) = Aspergillus flavus; type-10 (J1-J3) = Penicillium chermesinum; type-11 (K1-K3) = Penicillium paxilli; type-12 (L1-L3) = Microdochium phragmitis. (Bar $=20 \mu \mathrm{m})$. 
Table 2. Morphological characteristics of 12 morphotypes of the isolated fungal species based on colony and conidial characters.

\begin{tabular}{|c|c|c|c|c|}
\hline \multirow{2}{*}{ Morphotype } & \multicolumn{2}{|c|}{ Colony on PDA Media } & \multicolumn{2}{|r|}{ Conidia } \\
\hline & Morphology & Growth Rate (mm/Week) & Length $(\mu \mathrm{m})$ & Shape \\
\hline Type-1 & $\begin{array}{l}\text { Reddish-white and floccose } \\
\text { mycelia with deep red } \\
\text { pigmentation on the agar side. }\end{array}$ & $60-65$ & $20-25$ & $\begin{array}{l}\text { Obovate, ellipsoidal to } \\
\text { clavate and } 3-5 \text { septate in } \\
\text { macro-conidia. }\end{array}$ \\
\hline Type-2 & $\begin{array}{l}\text { Reddish to white with lavish } \\
\text { cottony mycelia. White to pale } \\
\text { yellow pigmentation on the } \\
\text { agar side. }\end{array}$ & $50-55$ & $26-45$ & $\begin{array}{l}\text { Oval, obovoid to allantoid } \\
\text { and macro-conidia slender } \\
\text { with 3-5 septate. }\end{array}$ \\
\hline Type-3 & $\begin{array}{c}\text { White grayish to dark grey, } \\
\text { light to dark reverse } \\
\text { pigmentation. }\end{array}$ & $55-60$ & $21-27$ & $\begin{array}{l}\text { Non-septate, hyaline, } \\
\text { falcate, and truncate. }\end{array}$ \\
\hline Type- 4 & $\begin{array}{l}\text { White to gray at the edge and } \\
\text { olivaceous buff in the center. }\end{array}$ & $55-60$ & $25-56$ & $\begin{array}{l}\text { Chains, obclavate, ovoid or } \\
\text { ellipsoid and three to seven } \\
\text { transverse septa. }\end{array}$ \\
\hline Type-5 & $\begin{array}{l}\text { Olive-brown to dark green with } \\
\text { gray-olivaceous to white edges, } \\
\text { velvet-like texture with radially } \\
\text { furrowed, dark pigmentation } \\
\text { on the agar side. }\end{array}$ & $35-40$ & $7-12$ & $\begin{array}{l}\text { Smooth, single-celled, } \\
\text { olive-brown, elliptical to } \\
\text { limonifor. }\end{array}$ \\
\hline Type-6 & $\begin{array}{l}\text { Lavish white and fluffy aerial } \\
\text { mycelium with dark to pale } \\
\text { brown from front and pigments } \\
\text { on the agar side. }\end{array}$ & $27-35$ & $13-34$ & $\begin{array}{l}\text { Macro-conidia with mostly } \\
\text { three to five-septae, slightly } \\
\text { curved to lunate at apex. }\end{array}$ \\
\hline Type-7 & $\begin{array}{l}\text { Dark brown to black colonies } \\
\text { with rough texture, white } \\
\text { mycelia underneath the } \\
\text { colonies. Whitish yellow radial } \\
\text { furrows at the backside. }\end{array}$ & $30-35$ & $4-5$ & $\begin{array}{c}\text { Dark brown to black } \\
\text { conidia, ellipsoidal, } \\
\text { phialides, spinose, borne in } \\
\text { radiate heads. }\end{array}$ \\
\hline Type- 8 & $\begin{array}{l}\text { Plane colonies, floccose from } \\
\text { center with strong sporulation, } \\
\text { no soluble pigment, and light } \\
\text { olive on the agar side. }\end{array}$ & $20-25$ & $3-4.5$ & $\begin{array}{c}\text { Globose conidia, } \\
\text { roughened and } \\
\text { yellow-brown to brown } \\
\text { at maturity. }\end{array}$ \\
\hline Type-9 & $\begin{array}{l}\text { Plain and flat at the edges, } \\
\text { raised at the center and } \\
\text { wrinkled cerebriform pattern, } \\
\text { produce greenish conidia with a } \\
\text { white border, cream color on } \\
\text { the agar side. }\end{array}$ & $20-25$ & $3-6$ & $\begin{array}{l}\text { Conidia with a thick } \\
\text { mycelial mat, globose } \\
\text { shape, thin walls and } \\
\text { rough texture. Metulae } \\
\text { obscured on the entire } \\
\text { surface of the vesicles. }\end{array}$ \\
\hline Type-10 & $\begin{array}{l}\text { Fast growing, white green-gray } \\
\text { shade, dense conidiophores, } \\
\text { and non-circular growth. }\end{array}$ & $22-25$ & $2.5-4$ & $\begin{array}{l}\text { Basocatenate, hyaline or } \\
\text { greenish, globose, } \\
\text { ellipsoidal, cylindrical or } \\
\text { fusiform, and smooth or } \\
\text { rough-walled. }\end{array}$ \\
\hline Type-11 & $\begin{array}{l}\text { Fast growing, white to light } \\
\text { green shade, dense } \\
\text { conidiophores with white edges } \\
\text { and irregular growth. }\end{array}$ & $18-25$ & $2.5-4$ & $\begin{array}{l}\text { Hyaline or greenish, } \\
\text { globose, ellipsoidal, } \\
\text { cylindrical, or fusiform. }\end{array}$ \\
\hline Type-12 & $\begin{array}{c}\text { Pinkish white flat colonies, } \\
\text { entire margins, slightly raised } \\
\text { to umbonate center and greyish } \\
\text { orange on the agar side. }\end{array}$ & $35-40$ & - & $\begin{array}{l}\text { No conidia produced in lab } \\
\text { condition. }\end{array}$ \\
\hline
\end{tabular}




\subsection{Molecular Characterization and Phylogenetic Analysis}

The highly conserved ITS-rDNA regions (500-600 bp) were sequenced for the 26 isolates. A homology search with the BLASTN program at NCBI showed that the sequences from the isolates showed almost $100 \%$ similarity to the reference sequences (Table 3 ). Interestingly, the results of the molecular identification were identical to those obtained after morphological characterization of the isolates and explained in Table 2. Therefore, the twelve morphotypes represent twelve different fungal species. The ITS-rDNA sequences were used to study the relationship between the identified taxa (Figure 3). The sequences were clustered into three classes of Ascomycota and comprised of twelve clades from which each clade presents one of the twelve isolated fungal morphotype. Isolates of the morphotypes 1-3, 6 , and 12 belong to the Sordariomycetes, morphotype 5 belongs to the Dothideomycetes, and morphotype 4 and 7-11 belong to the Eurotiomycetes. The GenBank accession numbers and details of reference sequences of the isolates used for the phylogenetic tree are presented in Table S1.

Table 3. Best BLAST matches for fungi based on ITS-rDNA regions.

\begin{tabular}{|c|c|c|c|c|c|c|}
\hline Isolates & Morpho-Type & $\begin{array}{l}\text { Accession } \\
\text { Numbers }^{\text {a }}\end{array}$ & Fungal Taxon & $\begin{array}{c}\text { Query Cover } \\
(\%)\end{array}$ & $\begin{array}{c}\text { Seq. Similarity } \\
(\%)\end{array}$ & $\begin{array}{l}\text { Accession Numbers } \\
\text { of ITS-rDNA }^{b}\end{array}$ \\
\hline YPF-1 & Type-1 & MW880893 & Fusarium kyushuense & 96 & 100 & КC466546 \\
\hline PPF-1 & Type-1 & MW880906 & Fusarium kyushuense & 100 & 100 & KC466546 \\
\hline PPF-2 & Type-1 & MW880907 & Fusarium kyushuense & 100 & 100 & KC466546 \\
\hline YPF-2 & Type-2 & MW880894 & Fusarium concentricum & 100 & 99 & MN341308 \\
\hline YPF-12 & Type-2 & MW880904 & Fusarium concentricum & 100 & 100 & LC317601 \\
\hline PPF-8 & Type-2 & MW880913 & Fusarium concentricum & 100 & 100 & LC317601 \\
\hline YPF-10 & Type-3 & MW880902 & Colletotrichum truncatum & 100 & 100 & JQ936246 \\
\hline YPF-11 & Type-3 & MW880903 & Colletotrichum truncatum & 100 & 100 & JQ936246 \\
\hline PPF-9 & Type-4 & MW880914 & Alternaria alternata & 100 & 100 & MN547372 \\
\hline PPF-10 & Type-4 & MW880915 & Alternaria alternata & 100 & 100 & MN547372 \\
\hline PPF-11 & Type-4 & MW880916 & Alternaria alternata & 100 & 100 & MT482506 \\
\hline PPF-12 & Type-4 & MW880917 & Alternaria alternata & 100 & 100 & MN547372 \\
\hline PPF-13 & Type-4 & MW880918 & Alternaria alternata & 100 & 100 & MN547372 \\
\hline YPF-9 & Type-5 & MW880901 & Cladosporium tenuissimum & 100 & 100 & MF422152 \\
\hline PPF-3 & Type-5 & MW880908 & Cladosporium tenuissimum & 100 & 100 & MF422152 \\
\hline PPF-4 & Type-5 & MW880909 & Cladosporium tenuissimum & 100 & 100 & MF422152 \\
\hline PPF-5 & Type-5 & MW880910 & Cladosporium tenuissimum & 100 & 100 & MF422152 \\
\hline YPF-13 & Type-6 & MW880905 & Fusarium equiseti & 100 & 100 & KR364600 \\
\hline YPF-3 & Type-7 & MW880895 & Aspergillus aculeatus & 99 & 99 & KU203321 \\
\hline YPF-4 & Type-7 & MW880896 & Aspergillus aculeatus & 100 & 100 & EU645733 \\
\hline PPF-7 & Type-7 & MW880912 & Aspergillus aculeatus & 100 & 100 & LC514695 \\
\hline YPF-5 & Type-8 & MW880897 & Aspergillus europaeus & 100 & 100 & FR727118 \\
\hline YPF-6 & Type-9 & MW880898 & Aspergillus flavus & 100 & 100 & MG228413 \\
\hline YPF-7 & Type-10 & MW880899 & Penicillium chermesinum & 100 & 100 & MK450679 \\
\hline PPF-6 & Type-11 & MW880911 & Penicillium paxilli & 100 & 98 & AB933278 \\
\hline YPF-8 & Type-12 & MW880900 & Microdochium phragmitis & 99 & 97 & AM502263 \\
\hline
\end{tabular}

\footnotetext{
${ }^{a}$ accession numbers of identified isolates in this study, ${ }^{b}$ accession numbers of reference isolates from GenBank.
} 


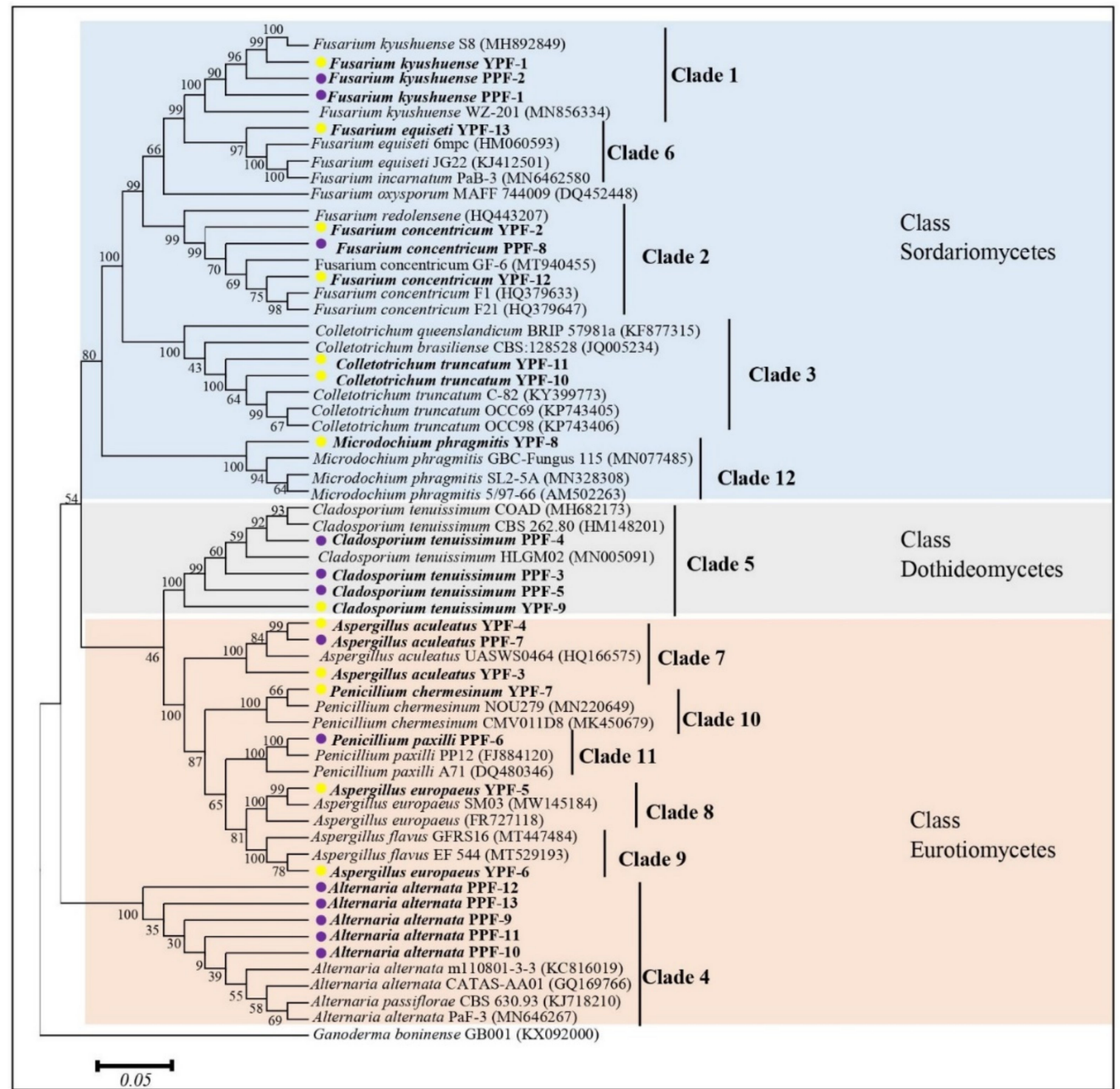

Figure 3. The evolutionary history of the twenty-six obtained isolates, presented in a phylogenetic tree on basis of neighbor joining and reference sequences from the NCBI GenBank database. The tree was constructed by analysis of ITS-rDNA sequences. Numbers at the nodes are the percentage of bootstrap support values of 1000 replicates. Ganoderma boninense GB001 (KX0920000) was used as an outgroup. The bar represents the 0.05 substitutions per nucleotide position and the isolates from the current study are presented in bold. Yellow and purple dots indicate the origin of the isolate.

\subsection{Pathogenicity Tests}

Inoculation was performed with wounded and non-wounded methods, as described in Material and Methods. To inspect the virulence of the isolates, the disease development (disease incidence percentage and the lesion diameter) of the fruits was recorded 4,8 , and 12 dpi (only 12 dpi data are shown). The morphotypes 1 to 6 of Fusarium, Colletotrichum, Alternaria, and Cladosporium were pathogenic and produced the obvious rot symptoms on inoculated yellow and purple fruits in the assays with wounded and non-wounded material (Figure 4), while the morphotypes 7 to 12 of Aspergillus, Penicillium, and Microdochium did not, and were considered nonpathogenic. Development of the disease incidences and lesion diameters after infection of both cultivars with the six pathogenic isolates uncovered significant differences. After infection of wounded and non-wounded fruits, local necrosis and discoloration were clearly visible 4 days after infection and the disease development propagated over the entire surface of the fruits until the 12th day. Consistent with the disease phenotype, at the end of the experiment, the entire fruit surfaces were covered with the mycelia of the six pathogens (Figure 4(A2-G2,A4-D4,H2-N2,H4-N4)). The wounded fruits of both cultivars showed clearly stronger disease symptoms than the unwounded (Figure 4(A5-G6,H5-N6)), and this was observed for both cultivars. Cross sections 12 days after the infection demonstrated that the disease symptoms of the unwounded yellow fruits 
were much stronger than in the unwounded purple fruits (Figure 4(H5-N6)). Furthermore, symptom development in both wounded and unwounded yellow fruits occurred earlier than in purple fruits and this is reflected by higher disease indices and lesion diameters. Therefore, the yellow fruits are more susceptible to pathogen infections than the purple fruits. The control fruits did not develop any decay symptoms (Figure 4(A1-A6,H1-H6)). Comparison of the pathogenicity of the six fungi revealed that F. kyushuense (type-1), F. concentricum (type-2), C. truncatum (type-3), and A. alternata (type-4) species developed larger lesions than C. tenuissimum (type-5), and F. equiseti (type-6). The disease incidence percentage and lesion diameter $(\mathrm{mm})$ of the pathogens are presented in Figure 5.

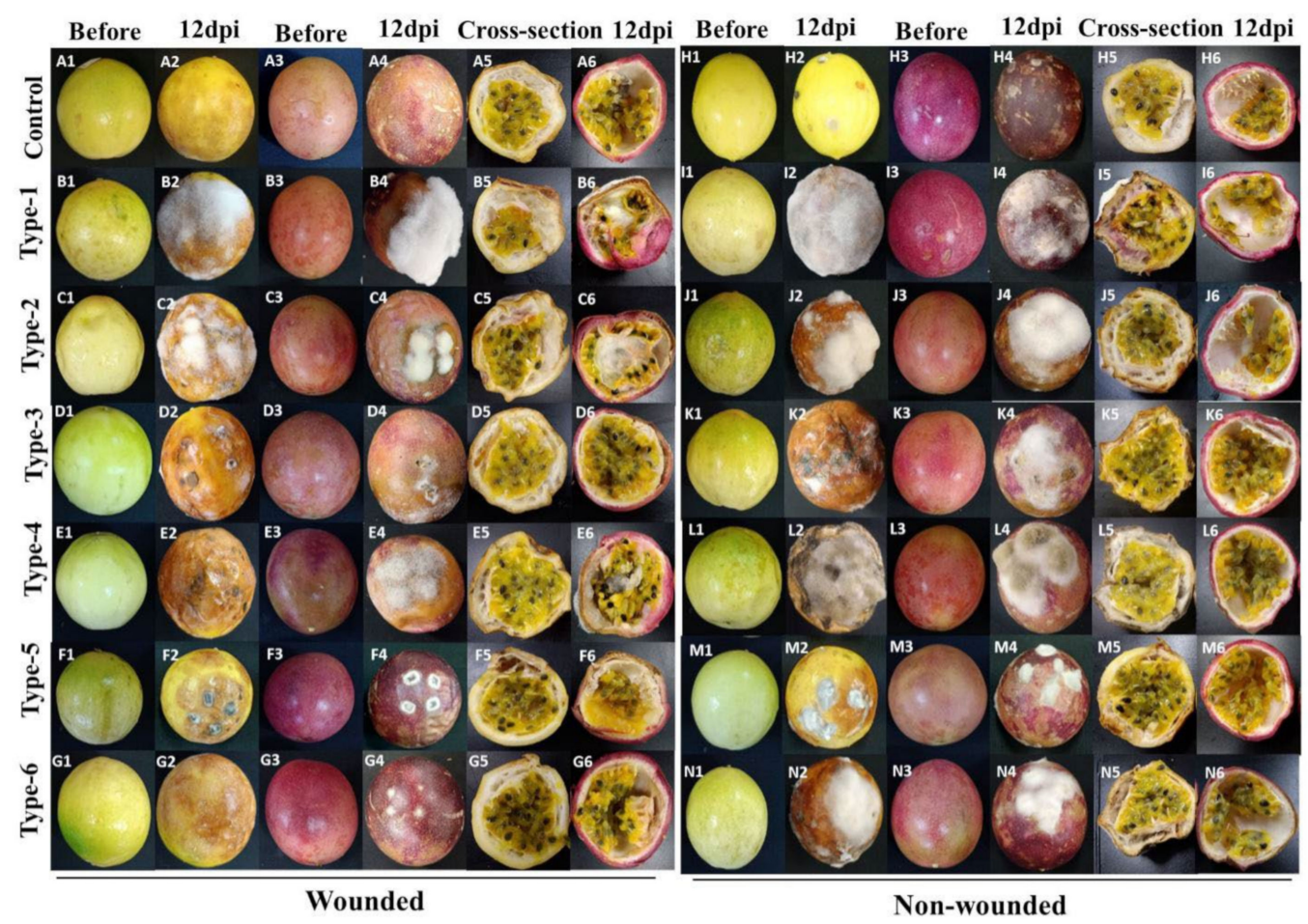

Figure 4. Pathogenicity of fungal isolates on two cultivars at 12 dpi. Type-1 (Fusarium kyushuense), type-2 (Fusarium concentricum), type-3 (Colletotrichum truncatum), type-4 (Alternaria alternata), type-5 (Cladosporium tenuissimum) and type-6 (Fusarium equiseti) isolates on yellow and purple passion fruits by wound $\left(1 \times 10^{6}\right.$ conidia $\mathrm{mL}^{-1}$ suspension) and non-wounded ( $5 \mathrm{~mm}$ mycelial plug) methods. A1-G6) fruits treated with $1 \times 10^{6}$ conidia $\mathrm{mL}^{-1}$ suspension of different fungal isolates using wound method, H1-N6) fruits treated with $5 \mathrm{~mm}$ mycelial plugs of different fungal isolates using non- wound method, A1-A6 \& H1-H6) fruits treated with water as control, B1-B6 \& I1-I6) fruits treated with Type-1 (Fusarium kyushuense) isolate, C1-C6 \& J1-J6) fruits treated with type-2 (Fusarium concentricum) isolate, D1-D6 \& K1-K6) fruits treated with type-3 (Colletotrichum truncatum) isolate, E1-E6 \& L1-L6) treated with type-4 (Alternaria alternata) isolate, F1-F6 \& M1-M6) fruits treated with type-5 (Cladosporium tenuissimum) isolate, G1-G8 \& N1-N6) fruits treated with type-6 (Fusarium equiseti) isolate.

\subsection{Phytohormones Levels in the Peels of the Fruit of the Yellow and Purple Cultivars}

The different susceptibility of the fruit of the two cultivars to pathogen infections led us to investigate their defense capacities. Since the peels are an important defense barrier, we analyzed whether they differ in their defense-related hormone composition (Table 4). The SA and JA levels were only slightly, but not significantly higher in the purple peels, and the level of the active jasmonate, jasmonoyl-isoleucine (JA-Ile), was even higher in the yellow peels. Interestingly, cis-12-oxophytodienoic acid (cis-OPDA), the JA precursor, is 7-times higher in the yellow peels, although the overall level is quite low. Furthermore, the yellow peels contain more than twice as much ABA than the purple peels (Table 4). Taken together, the defense-related phytohormones levels are not higher in the purple peels. 
The difference suggests that the hormones have different functions in the two cultivars (cf. discussion).
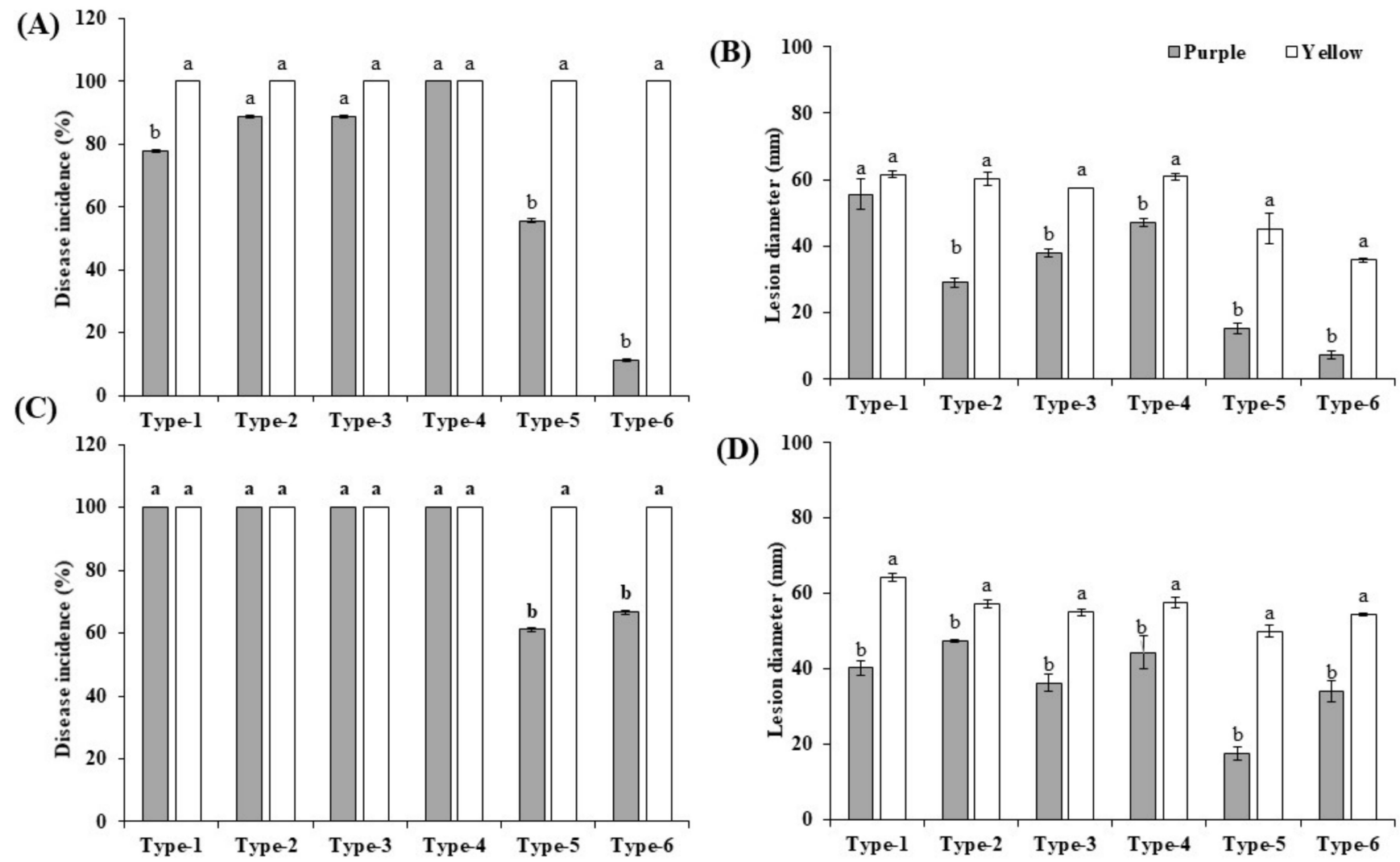

(D)

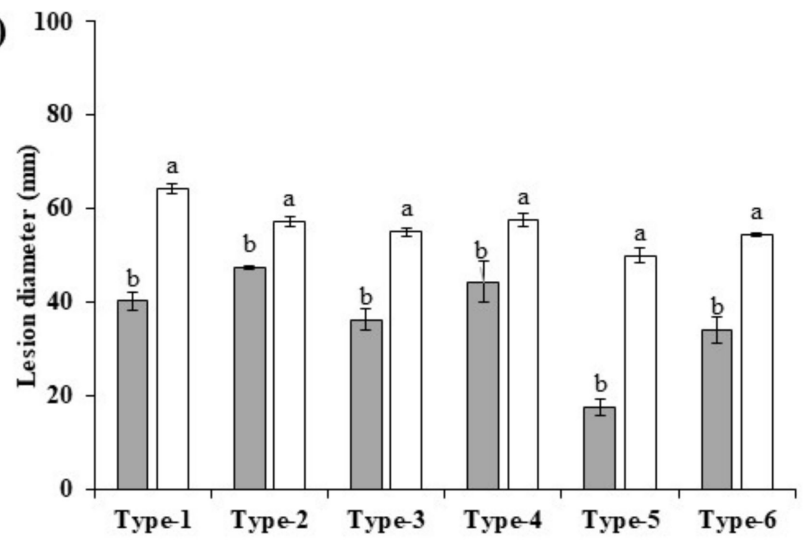

Figure 5. Determination of disease incidence (\%), lesion diameter ( $\mathrm{mm})$ at12 dpi on yellow and purple passion fruits, inoculated by type-1 (Fusarium kyushuense), type-2 (Fusarium concentricum), type-3 (Colletotrichum truncatum), type-4 (Alternaria alternata), type-5 (Cladosporium tenuissimum), and type-6 (Fusarium equiseti) isolates. Results shown were obtained from $(\mathbf{A}, \mathbf{B})$ wounded fruits $\left(1 \times 10^{6}\right.$ conidia $\mathrm{mL}^{-1}$ suspension $)$ and from $(\mathbf{C}, \mathbf{D})$ non-wounded fruits $(5 \mathrm{~mm}$ mycelial plug). Results are means \pm standard error. Different letters $(a / b)$ indicate significant differences between two cultivars.

Table 4. Phytohormones levels in the peels of yellow and purple fruit cultivars.

\begin{tabular}{|c|c|c|c|c|c|}
\hline $\begin{array}{l}\text { Fruit Peels } \\
\text { of Cultivar }\end{array}$ & $\begin{array}{c}\mathrm{SA} \\
\left(\mu \mathrm{g} \mathrm{kg}^{-1}\right)\end{array}$ & $\begin{array}{c}\mathrm{JA} \\
\left(\mu \mathrm{g} \mathrm{kg}^{-1}\right)\end{array}$ & $\begin{array}{c}\text { JA-Ile } \\
\left(\mu \mathrm{g} \mathrm{kg}^{-1}\right)\end{array}$ & $\begin{array}{c}\text { cis-OPDA } \\
\left(\mu \mathrm{g} \mathrm{kg}^{-1}\right)\end{array}$ & $\begin{array}{c}\text { ABA } \\
\left(\mu \mathrm{kg}^{-1}\right)\end{array}$ \\
\hline Purple & $504 \pm 81$ & $34 \pm 4$ & $1.3 \pm 0.3$ & $3.1 \pm 0.4$ & $1133 \pm 56$ \\
\hline Yellow & $449 \pm 73$ & $24 \pm 4$ & $2.2 \pm 0.4$ & $21.9 \pm 3$ & $2644 \pm 94$ \\
\hline
\end{tabular}

The results are based on five independent experiments and units describes the amount of phytohormones per $\mathrm{kg}$ of fruit fresh weight. Errors are SEs. SA, salicylic acid; JA, jasmonic acid; JA-Ile, jasmonoyl-isoleucine; cis-OPDA, cis-12-oxophytodienoic acid; ABA, abscisic acid.

\subsection{Gene Function Annotation, Expression, and Pathway Analysis}

We isolated RNA form the peels of the two cultivars and compared the expression profiles. Overall, about $1 / 3$ of all passion fruit genes are differentially expressed, and they represent almost all predicted biological processes (Table S2). An enrichment analysis identified those pathways, which contain the highest number of differently expressed genes (DEGs) in relation to the total gene numbers of the respective pathways (Figure 6). The biggest differences were observed for flavonoid biosynthesis (KEGG map00941), followed by DEGs categorized as "stilbenoid, diarylheptanoid, and gingerol biosynthesis" (KEGG map00945), "taurine and hypotaurine metabolism" (KEGG map00430), monoterpenoid biosynthesis (KEGG map00902), phenylalanine metabolism (KEGG map00360), brassinosteroid (KEGG map00905), and phenylpropanoid biosynthesis genes (KEGG map00940, 
Figure 6). Interestingly, defense-related and plant-pathogen-related genes are not enriched in one of the two cultivars, however, closer inspection uncovered that many defenserelated genes with predicted antifungal activities are much stronger ( $>4$-fold) up-regulated in the purple peels (Table 5). This includes genes for secondary metabolite biosynthesis, pathogenesis-related proteins, transporters, resistance and defense proteins, receptor kinases and defense signaling compounds, as well as regulators of redox homeostasis. As expected from the purple color, flavonoid biosynthesis genes, which include those for anthocyanin's (cf. below), are stronger expressed in the purple peels (Table 5, Figure 6). This is clearly visible from the KEGG pathway analyses, which shows that many genes for enzymes for the phenylpropanoid and flavonoid biosynthesis are higher expressed in the purple peels (Figure 7). Taken together, the highly enriched defense-related secondary metabolites in the purple peels provide a better barrier against fungal attacks than the yellow peels.

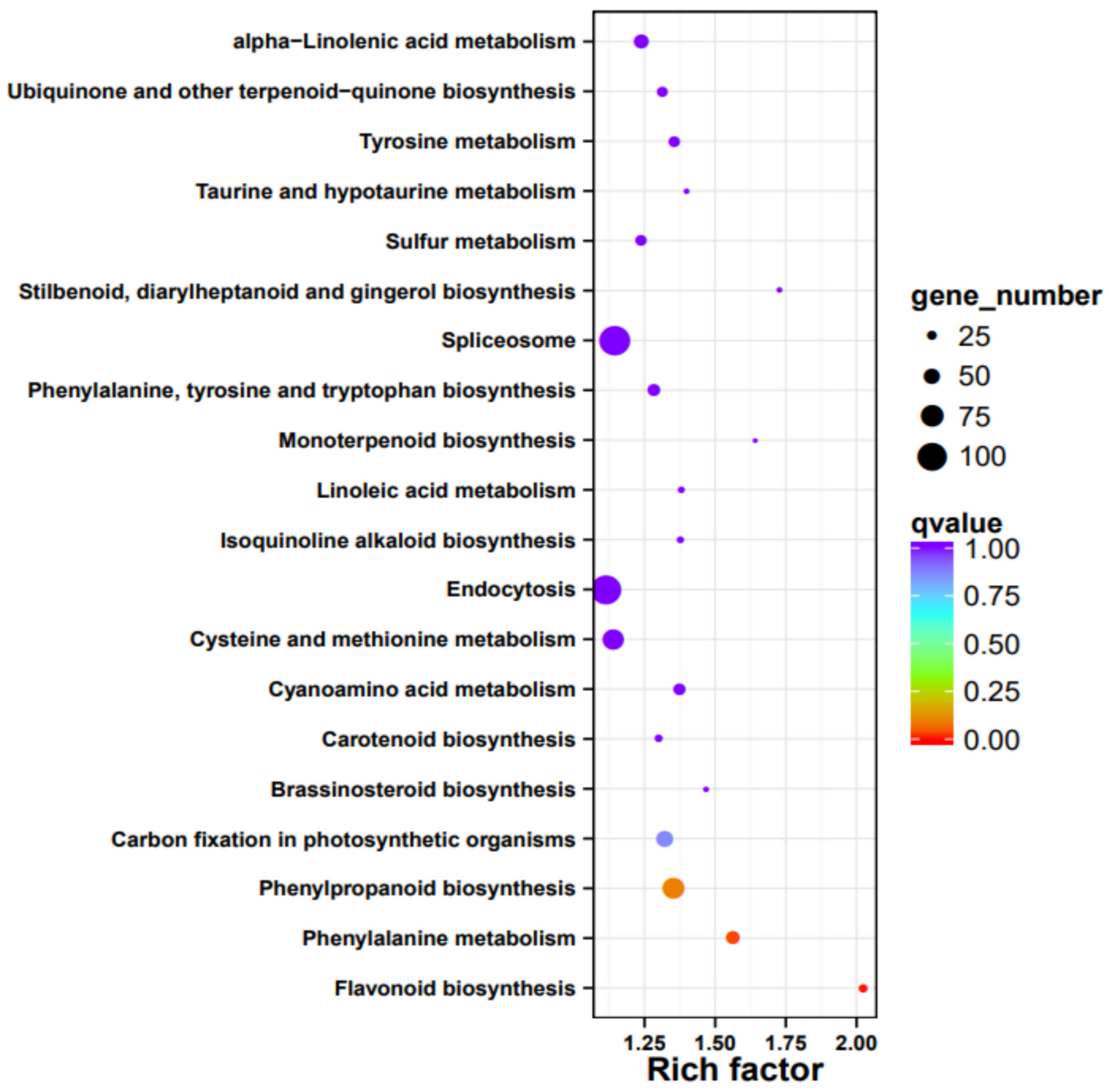

Figure 6. Pathway enrichment analysis based on the comparison of expression profiles from peels of purple vs. yellow fruits. Shown are the number of different sized dots (DEGs) of the top 20 regulated pathways. The rich factor on the $x$ axes indicates the number of DEGs per pathway compared to the total number of genes in this pathway. 
Table 5. Genes involved in various protection mechanisms with higher expression in the peels of the purple fruit in comparison to the yellow fruits. The data are based on three independent experiments.

\begin{tabular}{|c|c|c|}
\hline Unigenes & $\log _{2}$ Purple vs. Yellow & Gene Annotation \\
\hline 060661 & 3.2 & $\mathrm{ABC}$ transporter $\mathrm{C}$ family member \\
\hline 073495 & 3.2 & PLAT domain-containing protein \\
\hline 012452 & 3.2 & leucoanthocyanidin reductase \\
\hline 066444 & 3.2 & $\mathrm{ABC}$ transporter $\mathrm{G}$ family member \\
\hline 078965 & 3.2 & Toll-like receptor \\
\hline 079007 & 3.2 & $\mathrm{ABC}$ transporter $\mathrm{B}$ family member \\
\hline 157353 & 3.2 & glutathione S-transferase \\
\hline 075520 & 3.3 & disease resistance protein \\
\hline 066058 & 3.3 & AP2-like ethylene-responsive transcription factor \\
\hline 014357 & 3.3 & disease resistance protein \\
\hline 002704 & 3.5 & RALF protein \\
\hline 075276 & 3.5 & ethylene-responsive transcription factor \\
\hline 019034 & 3.6 & LRR receptor-like serine/threonine-protein kinase \\
\hline 080936 & 3.6 & LRR receptor-like serine/threonine-protein kinase \\
\hline 115445 & 3.6 & cellulose synthase subunit \\
\hline 006373 & 3.6 & allene oxide synthase \\
\hline 079086 & 3.6 & ethylene-responsive transcription factor \\
\hline 013300 & 3.7 & detoxification protein \\
\hline 072633 & 3.7 & MLO-like protein \\
\hline 058972 & 3.7 & ent-kaurene oxidase \\
\hline 065344 & 3.7 & callose synthase \\
\hline 012846 & 3.7 & disease resistance protein \\
\hline 077385 & 3.7 & ethylene-responsive transcription factor \\
\hline 013346 & 3.8 & salicylate carboxymethyltransferase \\
\hline 066699 & 3.9 & mechanosensitive ion channel \\
\hline 081472 & 3.9 & disease-resistance receptor-like protein kinase \\
\hline 045952 & 3.9 & pathogenesis-related protein \\
\hline 081029 & 3.9 & disease resistance protein \\
\hline 074186 & 3.9 & detoxification protein \\
\hline 092433 & 3.9 & ethylene-responsive transcription factor \\
\hline 076826 & 4.0 & ethylene-responsive transcription factor \\
\hline 029255 & 4.0 & remorin \\
\hline 099452 & 4.1 & PLAT domain-containing protein \\
\hline 034958 & 4.1 & flavonol synthase \\
\hline 005394 & 4.1 & detoxification protein \\
\hline 058910 & 4.2 & elicitor-responsive protein \\
\hline 151621 & 4.2 & 1-amino-cyclopropane-1-carboxylic acid oxidase \\
\hline 077400 & 4.2 & respiratory burst oxidase homolog protein $C$ \\
\hline 078602 & 4.3 & Downy Mildew Resistance protein \\
\hline 080595 & 4.3 & TMV resistance protein \\
\hline
\end{tabular}


Table 5. Cont.

\begin{tabular}{|c|c|c|}
\hline Unigenes & $\log _{2}$ Purple vs. Yellow & Gene Annotation \\
\hline 153053 & 4.3 & remorin \\
\hline 153975 & 4.3 & 1-aminocyclopropane-1-carboxylate oxidase \\
\hline 051447 & 4.5 & ethylene-responsive transcription factor \\
\hline 073788 & 4.6 & leucoanthocyanidin reductase \\
\hline 135950 & 4.7 & pathogenesis-related genes transcriptional activator \\
\hline 077933 & 4.7 & MLO-like protein \\
\hline 078748 & 4.7 & ethylene-responsive element-binding protein \\
\hline 018995 & 4.7 & monodehydroascorbate reductase \\
\hline 063867 & 4.8 & ethylene-responsive transcription factor \\
\hline 004586 & 4.8 & phenylalanine ammonia-lyase \\
\hline 081281 & 4.8 & leucine-rich repeat receptor-like serine/threonine kinase \\
\hline 013377 & 4.8 & 4-coumarate-CoA ligase \\
\hline 080912 & 4.9 & $\mathrm{ABC}$ transporter $\mathrm{B}$ family member \\
\hline 078836 & 4.9 & EIN3 domain-containing protein \\
\hline 079312 & 4.9 & $\mathrm{ABC}$ transporter $\mathrm{G}$ family member \\
\hline 078811 & 4.9 & multidrug resistance P-glycoprotein \\
\hline 009128 & 5.0 & ethylene receptor-like protein \\
\hline 058955 & 5.2 & monoterpene synthase \\
\hline 079862 & 5.2 & shikimate O-hydroxycinnamoyltransferase \\
\hline 076879 & 5.3 & linoleate 13S-lipoxygenase \\
\hline 115915 & 5.5 & disease resistance protein \\
\hline 017693 & 5.6 & terpene synthase \\
\hline 080270 & 5.6 & glutathione S-transferase \\
\hline 076381 & 5.6 & ABC transporter $G$ family member \\
\hline 147063 & 5.7 & ethylene-responsive transcription factor \\
\hline 073453 & 5.9 & flavonoid C-glucosyltransferase \\
\hline 141905 & 6.5 & chalcone-flavonone isomerase \\
\hline 077293 & 6.7 & terpene synthase \\
\hline 065968 & 7.1 & LRR receptor-like serine/threonine-protein kinase \\
\hline 074648 & 7.1 & ethylene-responsive transcription factor \\
\hline 058571 & 7.6 & flavonoid hydroxylase \\
\hline 073617 & 7.6 & remorin \\
\hline 134682 & 7.7 & leucoanthocyanidin reductase \\
\hline 063666 & 8.0 & sieve element occlusion protein \\
\hline 065392 & 8.2 & caffeoyl-CoA O-methyltransferase \\
\hline 081612 & 8.3 & malonyl-CoA:anthocyanidin 5-O-glucoside \\
\hline 006561 & 8.8 & naringenin-chalcone synthase \\
\hline 148145 & 9.4 & glutathione S-transferase \\
\hline 079417 & 9.7 & phenylalanine ammonia-lyase \\
\hline 015737 & 12.0 & glutathione S-transferase \\
\hline 051561 & 12.5 & naringenin,2-oxoglutarate 3-dioxygenase \\
\hline 079297 & 12.8 & leucoanthocyanidin dioxygenase \\
\hline
\end{tabular}




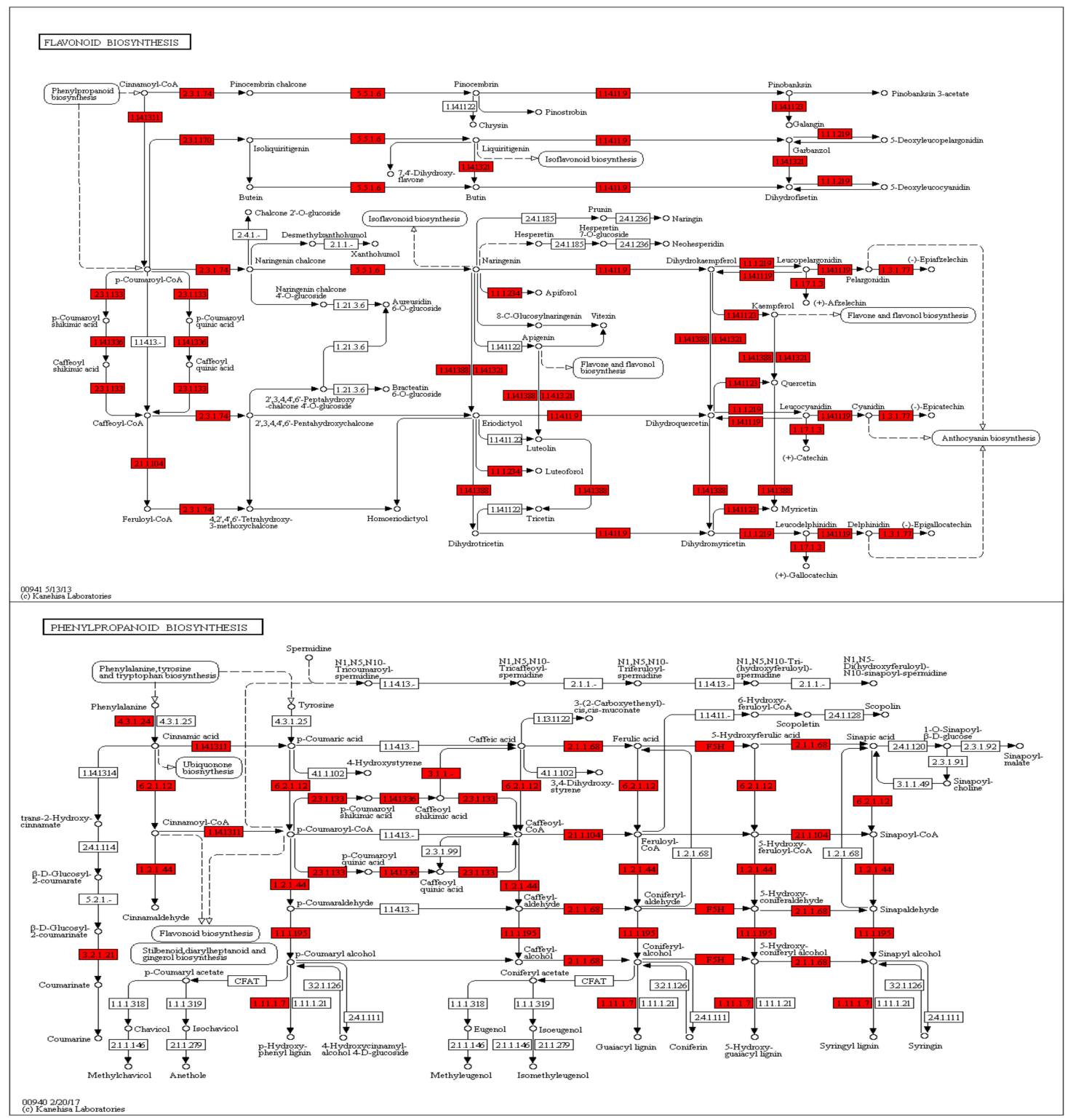

Figure 7. KEGG Mapper pathway analyses for enzymes involved in the flavonoid (top) and phenylpropanoid (bottom) biosynthesis. The genes for enzymes marked in red are higher expressed in the peels of the purple cultivar than the yellow cultivar. For experimental details, cf. Methods and Materials.

\subsection{Differences in the Metabolite Profiles of Purple and Yellow Peels}

The metabolite profile of both passion fruit varieties was analyzed; Table 6 shows the major identified compounds present in different concentrations in the two peels. The hypothesis that the color of the purple peels derives from anthocyanin was confirmed by identifying cyanidin-3-O-glucoside, and peonidin-3-O-glucoside as major component of their peels. In comparison, these two compounds were nearly absent in the peels of the yellow fruits. Additional antioxidants including catechin, epicatechin, and gallocatechin were found enriched in the purple peels. Several more flavonoids, which were not detectable in the yellow peels (for example peak 24, 25, Table 6), were detected in the purple ones. Their structure and function in the fruit is unknown and need to be analyzed in detail. In contrast to the previous observations, the flavonoid precursor phenylalanine itself was, with a five-fold concentration, more abundant in peels of the yellow fruits. Further detected components showed a significantly different content in the two varieties. Thus, the determined content of citric acid (peak 8, Table 6) was eight times higher in the purple peels, while other unknown compounds (peak 37, 38, Table 6) were enriched in the yellow fruits. 
Table 6. Mean peak intensities for metabolites partially identified in peels of the purple and yellow passion fruit cultivars by LC-ESI-Q-ToF-MS. (cf. Methods and Materials). Metabolites with highest intensities and differences between the purple and yellow cultivars are shown. Based on three independent experiments. Compounds are listed in order of retention time.

\begin{tabular}{|c|c|c|c|c|c|c|}
\hline Peak No. & $\begin{array}{l}\text { Molecular } \\
\text { Formula }\end{array}$ & $\begin{array}{l}\mathrm{m} / \mathrm{z} \text { Measured and } \\
\text { Ionization Mode }\end{array}$ & $\begin{array}{l}\text { Mean Intensity } \\
\text { Purple }\end{array}$ & $\begin{array}{c}\text { Mean Intensity } \\
\text { Yellow }\end{array}$ & $t$-Test & Identification \\
\hline 1 & $\mathrm{C}_{5} \mathrm{H}_{10} \mathrm{~N}_{2} \mathrm{O}_{3}$ & 147.0765-pos & 115,676 & 192,815 & 0.000 & glutamine \\
\hline 2 & $\mathrm{C}_{6} \mathrm{H}_{12} \mathrm{O}_{6}$ & 219.02657-pos & 102,721 & 56,375 & 0.000 & glucose \\
\hline 3 & $\mathrm{C}_{5} \mathrm{H}_{9} \mathrm{~N}_{1} \mathrm{O}_{4}$ & 148.06045-pos & 30,462 & 33,943 & 0.002 & glutamic acid \\
\hline 4 & $\mathrm{C}_{17} \mathrm{H}_{31} \mathrm{~N}_{1} \mathrm{O}_{15}$ & 490.17676-pos & 26,190 & 32,155 & 0.001 & unknown \\
\hline 5 & $\mathrm{C}_{12} \mathrm{H}_{22} \mathrm{O}_{11}$ & 341.1089-neg & 100,948 & 93,073 & 0.092 & sucrose \\
\hline 6 & $\mathrm{C}_{6} \mathrm{H}_{8} \mathrm{O}_{6}$ & 175.02481-neg & 119,067 & 65,947 & 0.001 & ascorbic acid \\
\hline 7 & $\mathrm{C}_{4} \mathrm{H}_{6} \mathrm{O}_{5}$ & 133.01433-neg & 164,764 & 153,107 & 0.028 & malic acid \\
\hline 8 & $\mathrm{C}_{8} \mathrm{H}_{8} \mathrm{O}_{7}$ & 191.01975-neg & 154,828 & 18,986 & 0.000 & citric acid \\
\hline 9 & $\mathrm{C}_{10} \mathrm{H}_{17} \mathrm{~N}_{3} \mathrm{O}_{6} \mathrm{~S}$ & 308.0911-pos & 59,473 & 48,847 & 0.035 & glutathione \\
\hline 10 & $\mathrm{C}_{10} \mathrm{H}_{13} \mathrm{~N}_{5} \mathrm{O}_{4}$ & 268.10409-pos & 220,255 & 301,724 & 0.002 & adenosine \\
\hline 11 & $\mathrm{C}_{5} \mathrm{H}_{4} \mathrm{O}_{4}$ & 129.01819-pos & 21,815 & 7486 & 0.000 & unknown \\
\hline 12 & $\mathrm{C}_{5} \mathrm{H}_{9} \mathrm{~N}_{1} \mathrm{O}_{2}$ & 116.0705-pos & 3322 & 3144 & 0.445 & proline \\
\hline 13 & $\mathrm{C}_{9} \mathrm{H}_{11} \mathrm{~N}_{1} \mathrm{O}_{3}$ & 182.08121-pos & 10,101 & 8574 & 0.323 & tyrosine \\
\hline 15 & $\mathrm{C}_{5} \mathrm{H}_{7} \mathrm{~N}_{1} \mathrm{O}_{3}$ & 130.04991-pos & 219,080 & 63,362 & 0.000 & 5-oxoproline \\
\hline 16 & $\mathrm{C}_{8} \mathrm{H}_{10} \mathrm{~N}_{1}$ & 166.0862-pos & 16,439 & 69,894 & 0.000 & phenylalanine \\
\hline 17 & $\mathrm{C}_{15} \mathrm{H}_{18} \mathrm{~N}_{4} \mathrm{O}_{11}$ & 431.1048-pos & 56,678 & 6094 & 0.001 & unknown \\
\hline 18 & $\mathrm{C}_{15} \mathrm{H}_{14} \mathrm{O}_{7}$ & 305.06663-neg & 39,016 & 0 & 0.000 & gallocatechin \\
\hline 19 & $\mathrm{C}_{22} \mathrm{H}_{22} \mathrm{O}_{11}$ & 463.12378-pos & 296,537 & 578 & 0.000 & peonidin-3-glucoside \\
\hline 20 & $\mathrm{C}_{15} \mathrm{H}_{14} \mathrm{O}_{6}$ & 291.08636-pos & 55,091 & 3370 & 0.000 & catechin \\
\hline 21 & $\mathrm{C}_{21} \mathrm{H}_{20} \mathrm{O}_{11}$ & 449.10812-pos & 114,061 & 2179 & 0.000 & cyanidin-3-O-glucoside \\
\hline 22 & $\mathrm{C}_{13} \mathrm{H}_{18} \mathrm{O}_{8}$ & 301.09273-neg & 54,632 & 2111 & 0.000 & unknown \\
\hline 23 & $\mathrm{C}_{26} \mathrm{H}_{34} \mathrm{O}_{12}$ & 537.1979-neg & 9365 & 5135 & 0.001 & citrusin A/hyuganoside III \\
\hline 24 & $\mathrm{C}_{21} \mathrm{H}_{22} \mathrm{O}_{11}$ & 449.10839-neg & 96,753 & 0 & 0.000 & unknown flavonoid \\
\hline 25 & $\mathrm{C}_{21} \mathrm{H}_{22} \mathrm{O}_{11}$ & 451.12317-pos & 94,078 & 0 & 0.000 & unknown flavonoid \\
\hline 26 & $\mathrm{C}_{26} \mathrm{H}_{34} \mathrm{O}_{12}$ & 537.19771-neg & 37,255 & 30,798 & 0.048 & citrusin A/hyuganoside III \\
\hline 27 & $\mathrm{C}_{15} \mathrm{H}_{14} \mathrm{O}_{6}$ & 291.08639-pos & 105,416 & 0 & 0.000 & epicatechin \\
\hline 28 & $\mathrm{C}_{20} \mathrm{H}_{27} \mathrm{~N}_{1} \mathrm{O}_{10}$ & 440.1564-neg & 278,197 & 173,262 & 0.005 & prunasin-rhamnoside \\
\hline 29 & $\mathrm{C}_{14} \mathrm{H}_{17} \mathrm{~N}_{1} \mathrm{O}_{6}$ & 296.1128-pos & 45,051 & 45,072 & 0.993 & prunasin \\
\hline 30 & $\mathrm{C}_{21} \mathrm{H}_{20} \mathrm{O}_{11}$ & 447.09301-neg & 7203 & 131,254 & 0.000 & C-glycosidic flavonoid \\
\hline 31 & $\mathrm{C}_{19} \mathrm{H}_{28} \mathrm{O}_{10}$ & 415.1602-neg & 1437 & 0 & 0.000 & unknown \\
\hline 32 & $\mathrm{C}_{27} \mathrm{H}_{30} \mathrm{O}_{14}$ & 579.17129-pos & 299,342 & 0 & 0.000 & unknown flavonoid \\
\hline 33 & $\mathrm{C}_{27} \mathrm{H}_{30} \mathrm{O}_{16}$ & 609.14553-neg & 125,726 & 1676 & 0.000 & unknown flavonoid \\
\hline 34 & $\mathrm{C}_{15} \mathrm{H}_{12} \mathrm{O}_{7}$ & 303.05087-neg & 32,535 & 0 & 0.000 & unknown \\
\hline 35 & $\mathrm{C}_{26} \mathrm{H}_{32} \mathrm{O}_{11}$ & 521.2031-neg & 22,200 & 7319 & 0.000 & unknown \\
\hline 36 & $\mathrm{C}_{21} \mathrm{H}_{20} \mathrm{O}_{12}$ & 463.08775-neg & 97,156 & 0 & 0.000 & unknown flavonoid \\
\hline 37 & $\mathrm{C}_{16} \mathrm{H}_{20} \mathrm{O}_{9}$ & 395.07389-pos & 26,622 & 49,305 & 0.117 & unknown \\
\hline 38 & $\mathrm{C}_{21} \mathrm{H}_{20} \mathrm{O}_{10}$ & 431.09818-neg & 622 & 30,081 & 0.000 & unknown \\
\hline 39 & $\mathrm{C}_{17} \mathrm{H}_{19} \mathrm{~N}_{1} \mathrm{O}_{9}$ & 382.11328-pos & 274,985 & 470,037 & 0.000 & prunasin malonate \\
\hline 40 & $\mathrm{C}_{27} \mathrm{H}_{30} \mathrm{O}_{13}$ & 561.16079-neg & 5768 & 129,117 & 0.000 & unknown \\
\hline 41 & $\mathrm{C}_{27} \mathrm{H}_{28} \mathrm{O}_{14}$ & 575.14075-neg & 82,622 & 1955 & 0.001 & unknown flavonoid \\
\hline 42 & $\mathrm{C}_{21} \mathrm{H}_{20} \mathrm{O}_{10}$ & 433.11323-pos & 115,448 & 941 & 0.000 & unknown \\
\hline
\end{tabular}




\section{Discussion}

Passion fruit has become an important commercial fruit with a high market value and large cultivation areas in China due to its favorable taste and phytonutrient ingredients [28-30]. However, the postharvest diseases limit its shelf life and market value and cause huge economic losses. The major postharvest decay symptoms and disease development depend strongly on the environmental and handling conditions. Previous studies identified the pathogens Zythia versoniana and Coniella granati as major causes for the dry decay [31] and Aspergillus niger for the soft decay [32]. Other reports identified the pathogenic Colletotrichum spp. [15,16], Lasiodiplodia spp. [17], and Phytophthora spp. [19] on the harvested fruits. Morphological analyses were described based on previous reports, and SSU, ITS, and LSU sequence data ultimately identified the fungal species (Table 3 and Table S1). A phylogenetic tree showed the relationship of the identified fungi to others (Figure 3). Pathogenicity studies showed that F. kyushuense, F. concentricum, C. truncatum, A. alternata, C. tenuissimum, and F. equiseti were pathogenic, while A. aculeatus, A. europaeus, A. flavus, P. chermesinum, P. paxilli, and M. phragmitis were not, since the re-infected fruit did not develop any detectable disease symptoms (Figures 4 and 5). The six pathogenic fungi cause severe disease symptoms on wounded and unwounded yellow and purple passion fruit and have not yet been reported in the context of decay on harvested passion fruits. They belong to a well-known group of fungi involved in diseases on other host plants, such as Fusarium spp. on apple, citrus, banana, and blueberry, Colletotrichum spp. on strawberry, apple, citrus, and papaya, Alternaria spp. on apple, citrus, grapes, mango, pomegranate and Cladosporium spp. on grapes, pears, and raspberries.

Thrane, Adler [33] reported that F. kyushuense strains produce the secondary metabolites aurofusarin, nivalenol, enniatin B and several aflatoxins. Therefore, uncontrolled growth of this fungal strain in the passion fruit could cause diseases during human consumption. On the other hand, C. tenuissimum produces Cladosporol A, a secondary metabolite, which exhibits antiproliferative properties in human colorectal cancer cells by modulating the expression of cell cycle genes [34]. Besides fungal products with negative effects on human consumption, F. concentricum and F. equiseti produce the well-known mycotoxin fusaric acid that plays an important role in plant pathology [35]. In addition, C. truncatum is a major cause for anthracnose in many crops including chili. Mishra, Mohanty [36] identified the chili can-miRn37a miRNA, which represses the expression of ethylene-response transcription factors and thus prevents fungal colonization and disease development. The large number of identified genes for ethylene-responsive transcription factors in the purple cultivar (Table 5) may contribute to the restriction of $C$. truncatum growth in the fruits. Furthermore, some of the fungal strains, which induce disease symptoms in infected fruit, may also have beneficial features in other organs, developmental stages, or microbial communities in the plant tissue. For instance, the F. equiseti strain GF19-1 is known as a plant-growth promoting fungus which induces systemic resistance via the SA pathway in Arabidopsis [37]. It shows pathogenic feature when inoculated alone to the passion fruit, however this might be restricted by other microbes, which are normally also present in the passion fruits.

Interestingly, one-third of the identified fungi do not cause pathogenic symptoms and they might function as beneficial symbionts. Aspergillus aculeatus has been reported as beneficial symbiont which confers salt, drought, heat and cadmium tolerance to the perennial ryegrass $[38,39]$. Aspergillus flavus is an opportunistic fungal plant and human pathogen because it produces mycotoxins, including aflatoxin $B_{1}$, as well as other toxic secondary metabolites. In addition to infecting important crops, $A$. flavus also causes a deadly lung infection known as invasive aspergillosis. Although A. flavus is the second leading cause of this disease, after Aspergillus fumigatus, infections caused by A. flavus are 100-fold more virulent than those caused by A. fumigatus [40]. The two identified endophytic Penicillium species (P. chermesinum, P. paxilli) have multiple agricultural, biotechnological, and pharmaceutical applications, and might be interesting candidates for the isolation of antiparasitic agents or plant growth-promoting substances [41]. Ernst, Neubert [42] 
investigated niche partitioning of the two closely related fungal endophytes, $M$. bolleyi and M. phragmitis, which colonize Phragmites australis. Interestingly, the host habitat significantly differentiated the two species, whereas the latter one (also identified in this study) favors flooded regions. This fungus might be an indicator for the air moisture during fruit handling, storage, and transport. In summary, it is important for the food industry to know which fungi are associated with the passion fruits. Some of them might not cause disease symptoms in plants, but propagate in the harvested fruit and can produce toxins for humans. On the other hand, the beneficial microbes might restrict the spread of the pathogens, and the established equilibrium in the fungal populations might be important for the food quality.

\subsection{Comparison of the Fruit of the Yellow and Purple Cultivar}

The re-infection assays clearly demonstrated that the yellow fruit are more susceptible for pathogen infections than the purple fruit (Figures 4 and 5). As expected, fruit with intact peels perform better than those in injured peels. Our results are similar with the previous report by Cerqueira-Silva, Jesus [43] in which the comparative results suggested that the purple passion fruit is resistant to woodiness virus. The comparative omics analyses of the peels of the two cultivars uncovered compounds, which might participate in, or are even responsible for, better resistance of the purple cultivar against pathogenic fungal infections.

\subsection{Hormones}

Analyses of the defense-related phytohormones concentrations suggest that they play different roles in the peels of the two cultivars. As expected, the SA and JA levels in the uninfected peels of both cultivars are quite low (Table 4). Since both hormones are induced upon pathogen infections, this result is not surprising, although several reports showed that fruit may have high SA levels to protect them against biotrophic pathogen attacks [44] The oxylipin cis-OPDA is a precursor of jasmonates, but has also quite different defense signaling functions [45]. cis-OPDA can be esterified to galactolipids and the resulting compounds are thought to act as a rapidly available cis-OPDA source. Furthermore, cis-OPDA has been proposed to interact with ABA [46]. The elevated cis-OPDA level in the yellow peels may allow a faster activation of JA-dependent defense responses upon pathogen attack, the crosslink to ABA may promote lignin deposition in response to environmental stress [47]. Lignin deposition requires cell wall rearrangement, and the peels of ripening fruit undergo substantial softening, which require ABA-induced transcriptional changes in cell wall degrading enzymes [48]. As outlined by Forlani, Masiero [49], the multiple roles of $\mathrm{ABA}$ during fruit ripening makes it difficult to relate them to specific responses. In conclusion: comparison of both cultivars suggest that the yellow peels utilize more cis-OPDA and ABA for stress responses, and that elevated ABA level may also protect them better against abiotic stress [50].

\subsection{Expression and Metabolite Profiles}

An interesting observation is that about $1 / 3$ of all genes are differentially expressed in the peels of the two cultivars and this pattern is more or less found for genes belonging to all biochemical pathways (Table 5 and Table S2). Consistent with the metabolite profiles, the KEGG analyses clearly shows that a huge number of genes for the phenylpropanoid and flavonoid pathways are much stronger expressed in the purple peels. The color of the fruit of the purple cultivar is caused by the anthocyanin cyanidin-3-O-glucoside. Together with peonidin-3-glucoside and the flavonoids, which are present in the purple fruits, these secondary metabolites clearly participate in plant defense against several stresses including pathogenic fungi [51]. Catechin, gallocatechin, and epicatechin have antioxidant and anti-inflammatory activities [52]. These results indicate that major metabolites, which are present in the purple, and reduced or missing in the yellow fruit, restricts pathogen growth on the fruits. The analysis of the DEGs also uncovered that those for antioxidant enzymes and proteins, receptors and signaling compounds for pathogen- 
associated molecular patterns, transporters predicted to be involved in detoxification and ion transport, redox regulators, and systemic signal propagation are much higher expressed in the purple peels (Figures 6 and 7). Overall, the purple peels invest more in cell-protective functions and biotic stress responses.

\section{Conclusions}

This analyses uncovered pathogenic and non-pathogenic fungi, which are present on harvested passion fruits. Six pathogenic fungal species induce post-harvest rots; fruit of the yellow cultivar are more susceptible than the fruit of the purple cultivar. The comparative analyses of the peels suggest that flavonoids and phenylpropanoids might be responsible for the better resistance of the purple peels to decay development. The role of the nonpathogenic fungi requires further investigations. They might restrict pathogen growth, participate in strengthening the immunity of the harvested fruit, and might provide an important link between disease symptom development and pathogen resistance of the harvested fruits. The identified microorganisms as well as the obtained datasets for the fruit of the two cultivars provide a valuable source for future research on the control of postharvest passion fruit decay, which will be beneficial for the passion fruit industry.

Supplementary Materials: The following are available online at https:/ / www.mdpi.com/article/1 0.3390/jof7100879/s1, Figure S1: Morphological characterization of the 26 isolates collected from passionfruit postharvest. Table S1: GenBank accession numbers of sequences used for phylogenetic analyses. Table S2: Number of DEGs of all genes for the annotated pathways in the peels of the fruits of the purple and yellow passion fruit cultivars.

Author Contributions: Conceptualization, H.M.R., L.Z. and F.C.; methodology, W.H., A.W., L.Z., Y.Q., A.F.Y., N.M. and X.W.; software, H.M.R. and W.H., validation, H.M.R. and F.C.; data curation, H.M.R., S.S.S. and M.R.; writing—original draft preparation, H.M.R.; writing—review and editing, S.S.S., M.R., R.O. and F.C.; supervision, F.C.; project administration, F.C.; funding acquisition, F.C and L.Z. All authors have read and agreed to the published version of the manuscript.

Funding: This research was funded by the Science and Technology Department of Fujian Province (2020N0004, 2020S0056) to F.C. and the plant biological seedling science and technology innovation team (CXTD2021009-03) to L.Z.

Institutional Review Board Statement: Not applicable.

Informed Consent Statement: Not applicable.

Data Availability Statement: The pathogen sequence datasets were analyzed in this study and deposited to GenBank under accession number MW880893-MW880918.

Conflicts of Interest: The authors declare no conflict of interest.

\section{References}

1. De Toledo, N.M.V.; De Camargo, A.C.; Ramos, P.B.M.; Button, D.C.; Granato, D.; Canniatti-Brazaca, S.G. Potentials and Pitfalls on the Use of Passion Fruit By-Products in Drinkable Yogurt: Physicochemical, Technological, Microbiological, and Sensory Aspects. Beverages 2018, 4, 47. [CrossRef]

2. FAO. Minor Tropical Fruits; Food and Agriculture Organization of United Nation: Rome, Italy, 2018. Available online: http:/ / www.fao.org/fileadmin/templates/est/COMM_MARKETS_MONITORING/Tropical_Fruits/Documents/Minor_Tro pical_Fruits_FoodOutlook_1_2018.pdf (accessed on 11 October 2020).

3. Antognoni, F.; Zheng, S.; Pagnucco, C.; Baraldi, R.; Poli, F.; Biondi, S. Induction of flavonoid production by UV-B radiation in Passiflora quadrangularis callus cultures. Fitoterapia 2007, 78, 345-352. [CrossRef] [PubMed]

4. Zeraik, M.L.; Yariwake, J. Quantification of isoorientin and total flavonoids in Passiflora edulis fruit pulp by HPLC-UV/DAD. Microchem. J. 2010, 96, 86-91. [CrossRef]

5. Liu, S.; Li, A.; Chen, C.; Cai, G.; Zhang, L.; Guo, C.; Xu, M. De Novo Transcriptome Sequencing in Passiflora edulis Sims to Identify Genes and Signaling Pathways Involved in Cold Tolerance. Forests 2017, 8, 435. [CrossRef]

6. Brasil, I.M.; Siddiqui, M.W. Postharvest quality of fruits and vegetables: An overview. In Preharvest Modulation of Postharvest Fruit and Vegetable Quality; Elsevier: Cambridge, MA, USA, 2018; pp. 1-40.

7. Aulakh, J.; Regmi, A.; Fulton, J.R.; Alexander, C.E. Estimating Post-Harvest Food Losses: Developing A Consistent Global Estimation Framework; Joint Annual Meeting: Washington, DC, USA, 2013. 
8. Dutra, J.B.; Blum, L.E.B.; Lopes, L.F.; Cruz, A.F.; Uesugi, C.H. Use of hot water, combination of hot water and phosphite, and 1-MCP as post-harvest treatments for passion fruit (Passiflora edulis $\mathrm{f}$. flavicarpa) reduces anthracnose and does not alter fruit quality. Hortic. Environ. Biotechnol. 2018, 59, 847-856. [CrossRef]

9. Gustavsson, J.; Cederberg, C.; Sonesson, U.; Van Otterdijk, R.; Meybeck, A. Global Food Losses and Food Waste; FAO: Rome, Italy, 2011.

10. Alkan, N.; Fortes, A.M. Insights into molecular and metabolic events associated with fruit response to post-harvest fungal pathogens. Front. Plant Sci. 2015, 6, 889. [CrossRef] [PubMed]

11. Perez, M.F.; Contreras, L.; Garnica, N.M.; Fernández-Zenoff, M.V.; Farias, M.E.; Sepulveda, M.; Ramallo, J.; Dib, J.R. Native Killer Yeasts as Biocontrol Agents of Postharvest Fungal Diseases in Lemons. PLoS ONE 2016, 11, e0165590. [CrossRef] [PubMed]

12. Palou, L.; Montesinos-Herrero, C.; Tarazona, I.; Besada, C.; Taberner, V. Incidence and Etiology of Postharvest Fungal Diseases of Persimmon (Diospyros kaki Thunb. cv. Rojo Brillante) in Spain. Plant Dis. 2015, 99, 1416-1425. [CrossRef] [PubMed]

13. Kamle, M.; Kumar, P.; Gupta, V.K.; Tiwari, A.K.; Misra, A.K.; Pandey, B.K. Identification and phylogenetic correlation among Colletotrichum gloeosporioides pathogen of anthracnose for mango. Biocatal. Agric. Biotechnol. 2013, 2, 285-287. [CrossRef]

14. Damm, U.; Sato, T.; Alizadeh, A.; Groenewald, J.Z.; Crous, P.W. The Colletotrichum dracaenophilum, C. ámagnum and C. áorchidearum species complexes. Stud. Mycol. 2019, 92, 1-46. [CrossRef]

15. Qiu, F.; Li, X.; Xie, C.P.; Li, J.; Zheng, F.Q. Identification of Colletotrichum brevisporum causing fruit rot in yellow passion fruit (Passiflora edulis f. flavicarpa) in China. Australas. Plant Pathol. 2021, 50, 229-232. [CrossRef]

16. Peres, N.A.R.; Kuramae, E.; Dias, M.S.C.; De Souza, N.L. Identification and Characterization of Colletotrichum spp. affecting Fruit after Harvest in Brazil. J. Phytopathol. 2002, 150, 128-134. [CrossRef]

17. Zhang, W.; Niu, X.L.; Yang, J.Y. First Report of Postharvest Fruit Rot on Passion Fruit (Passiflora edulis) Caused by Lasiodiplodia theobromae in Mainland China. Plant Dis. 2021, 105, 1198. [CrossRef]

18. Muniz, M.; Rocha, D.F.; Silveira, N.S.S.; Menezes, M. Identification of fungi causal agents of postharvest diseases on commercialized fruits in Alagoas, Brazil. Summa Phytopathol. 2003, 29, 38-42.

19. Gil, J.G.R.; Tamayo, P.J.; Morales, J.G. Identification and pathogenicity of microorganisms affecting purple passion fruit in Colombia. Rev. Ceres 2017, 64, 250-257. [CrossRef]

20. Schoch, C.L.; Seifert, K.A.; Huhndorf, S.; Robert, V.; Spouge, J.L.; Levesque, C.A.; Chen, W. Fungal Barcoding Consortium. Nuclear ribosomal internal transcribed spacer (ITS) region as a universal DNA barcode marker for Fungi. Proc. Natl. Acad. Sci. USA 2012, 109, 6241-6246. [CrossRef] [PubMed]

21. Raja, H.A.; Miller, A.N.; Pearce, C.J.; Oberlies, N.H. Fungal Identification Using Molecular Tools: A Primer for the Natural Products Research Community. J. Nat. Prod. 2017, 80, 756-770. [CrossRef] [PubMed]

22. Harsonowati, W.; Marian, M.; Surono Narisawa, K. The Effectiveness of a Dark Septate Endophytic Fungus, Cladophialophora chaetospira SK51, to Mitigate Strawberry Fusarium Wilt Disease and with Growth Promotion Activities. Front. Microbiol. 2020, 11, 585. [CrossRef] [PubMed]

23. Manter, D.K.; Vivanco, J.M. Use of the ITS primers, ITS1F and ITS4, to characterize fungal abundance and diversity in mixedtemplate samples by qPCR and length heterogeneity analysis. J. Microbiol. Methods 2007, 71, 7-14. [CrossRef]

24. Zarrin, M.; Ganj, F.; Faramarzi, S. Analysis of the rDNA internal transcribed spacer region of the Fusarium species by polymerase chain reaction-restriction fragment length polymorphism. Biomed. Rep. 2016, 4, 471-474. [CrossRef] [PubMed]

25. White, T.J.; Bruns, T.; Lee, S.; Taylor, J. Amplification and direct sequencing of fungal ribosomal RNA genes for phylogenetics. In PCR Protocols: A Guide to Methods and Applications; Innis, M., Gelfand, D., Sninsky, J., White, T., Eds.; Academic Press Inc.: New York, NY, USA, 1990; pp. 315-322.

26. Hu, Y.; Jiao, L.; Jiang, M.-H.; Yin, S.; Dong, P.; Zhao, Z.-M.; Yang, D.-P.; Ho, P.-T.; Wang, D.-M. A new C-glycosyl flavone and a new neolignan glycoside from Passiflora edulis Sims peel. Nat. Prod. Res. 2018, 32, 2312-2318. [CrossRef]

27. Farag, M.A.; Otify, A.; Porzel, A.; Michel, C.G.; Elsayed, A.; Wessjohann, L.A. Comparative metabolite profiling and fingerprinting of genus Passiflora leaves using a multiplex approach of UPLC-MS and NMR analyzed by chemometric tools. Anal. Bioanal. Chem. 2016, 408, 3125-3143. [CrossRef] [PubMed]

28. He, X.; Luan, F.; Yang, Y.; Wang, Z.; Zhao, Z.; Fang, J.; Wang, M.; Zuo, M.; Li, Y. Passiflora edulis: An Insight Into Current Researches on Phytochemistry and Pharmacology. Front. Pharmacol. 2020, 11, 617. [CrossRef] [PubMed]

29. Li, C.; Xin, M.; Li, L.; He, X.; Liu, G.; Li, J.; Sheng, J.; Sun, J. Transcriptome profiling helps to elucidate the mechanisms of ripening and epidermal senescence in passion fruit (Passiflora edulia Sims). PLoS ONE 2020, 15, e0236535. [CrossRef]

30. Yan, C.; Rizwan, H.M.; Liang, D.; Reichelt, M.; Mithöfer, A.; Scholz, S.S.; Oelmüller, R.; Chen, F. The effect of the root-colonizing Piriformospora indica on passion fruit (Passiflora edulis) development: Initial defense shifts to fitness benefits and higher fruit quality. Food Chem. 2021, 359, 129671. [CrossRef] [PubMed]

31. Tziros, G.; Tzavella-Klonari, K. Pomegranate fruit rot caused by Coniella granati confirmed in Greece. Plant Pathol. 2008, 57, 783.

32. Li, X.; Lu, X.; He, Y.; Deng, M.; Lv, Y. Identification the Pathogens Causing Rot Disease in Pomegranate (Punica granatum L.) in China and the Antifungal Activity of Aqueous Garlic Extract. Forests 2019, 11, 34. [CrossRef]

33. Thrane, U.; Adler, A.; Clasen, P.-E.; Galvano, F.; Langseth, W.; Lew, H.; Logrieco, A.F.; Nielsen, K.F.; Ritieni, A. Diversity in metabolite production by Fusarium langsethiae, Fusarium poae, and Fusarium sporotrichioides. Int. J. Food Microbiol. 2004, 95, 257-266. [CrossRef] 
34. Zurlo, D.; Assante, G.; Moricca, S.; Colantuoni, V.; Lupo, A. Cladosporol A, a new peroxisome proliferator-activated receptor $\gamma$ $(\mathrm{PPAR} \gamma)$ ligand, inhibits colorectal cancer cells proliferation through $\beta$-catenin/TCF pathway inactivation. Biochim. Biophys. Acta (BBA)—Gen. Subj. 2014, 1840, 2361-2372. [CrossRef]

35. Shi, W.; Tan, Y.; Wang, S.; Gardiner, D.M.; De Saeger, S.; Liao, Y.; Wang, C.; Fan, Y.; Wang, Z.; Wu, A. Mycotoxigenic Potentials of Fusarium Species in Various Culture Matrices Revealed by Mycotoxin Profiling. Toxins 2016, 9, 6. [CrossRef]

36. Mishra, R.; Mohanty, J.N.; Chand, S.K.; Joshi, R.K. Can-miRn37a mediated suppression of ethylene response factors enhances the resistance of chilli against anthracnose pathogen Colletotrichum truncatum L. Plant Sci. 2018, 267, 135-147. [CrossRef] [PubMed]

37. Kojima, H.; Hossain, M.; Kubota, M.; Hyakumachi, M. Involvement of the salicylic acid signaling pathway in the systemic resistance induced in Arabidopsis by plant growth-promoting fungus Fusarium equiseti GF19-1. J. Oleo Sci. 2013, 62, 415-426. [CrossRef] [PubMed]

38. Li, X.; Han, S.; Wang, G.; Liu, X.; Amombo, E.; Xie, Y.; Fu, J. The Fungus Aspergillus aculeatus Enhances Salt-Stress Tolerance, Metabolite Accumulation, and Improves Forage Quality in Perennial Ryegrass. Front. Microbiol. 2017, 8, 1664. [CrossRef] [PubMed]

39. Li, X.; Zhao, C.; Zhang, T.; Wang, G.; Amombo, E.; Xie, Y.; Fu, J. Exogenous Aspergillus aculeatus Enhances Drought and Heat Tolerance of Perennial Ryegrass. Front. Microbiol. 2021, 12, 307.

40. Lohmar, J.M.; Puel, O.; Cary, J.W.; Calvo, A.M. The Aspergillus flavus rtfA Gene Regulates Plant and Animal Pathogenesis and Secondary Metabolism. Appl. Environ. Microbiol. 2019, 85, e02446-18. [CrossRef] [PubMed]

41. Toghueo, R.M.K.; Boyom, F.F. Endophytic Penicillium species and their agricultural, biotechnological, and pharmaceutical applications. 3 Biotech 2020, 10, 107. [CrossRef]

42. Ernst, M.; Neubert, K.; Mendgen, K.W.; Wirsel, S.G. Niche differentiation of two sympatric species of Microdochium colonizing the roots of common reed. BMC Microbiol. 2011, 11, 242. [CrossRef] [PubMed]

43. Cerqueira-Silva, C.B.M.; Jesus, O.N.; Oliveira, E.; Santos, E.S.L.; Souza, A.P. Characterization and selection of passion fruit (yellow and purple) accessions based on molecular markers and disease reactions for use in breeding programs. Euphytica 2015, 202, 345-359. [CrossRef]

44. Duthie, G.G.; Wood, A.D. Natural salicylates: Foods, functions and disease prevention. Food Funct. 2011, 2, 515-520. [CrossRef]

45. Maynard, D.; Gröger, H.; Dierks, T.; Dietz, K.-J. The function of the oxylipin 12-oxophytodienoic acid in cell signaling, stress acclimation, and development. J. Exp. Bot. 2018, 69, 5341-5354. [CrossRef]

46. Dave, A.; Graham, I.A. Oxylipin Signaling: A Distinct Role for the Jasmonic Acid Precursor cis-(+)-12-Oxo-Phytodienoic Acid (cis-OPDA). Front. Plant Sci. 2012, 3, 42. [CrossRef] [PubMed]

47. Liu, C.; Yu, H.; Rao, X.; Li, L.; Dixon, R.A. Abscisic acid regulates secondary cell-wall formation and lignin deposition in Arabidopsis thaliana through phosphorylation of NST1. Proc. Natl. Acad. Sci. USA 2021, 118, e2010911118.

48. Moya-León, M.A.; Mattus-Araya, E.; Herrera, R. Molecular Events Occurring During Softening of Strawberry Fruit. Front. Plant Sci. 2019, 10, 615. [CrossRef] [PubMed]

49. Forlani, S.; Masiero, S.; Mizzotti, C. Fruit ripening: The role of hormones, cell wall modifications, and their relationship with pathogens. J. Exp. Bot. 2019, 70, 2993-3006. [CrossRef]

50. Leng, P.; Yuan, B.; Guo, Y. The role of abscisic acid in fruit ripening and responses to abiotic stress. J. Exp. Bot. 2013, 65, 4577-4588. [CrossRef] [PubMed]

51. Zaynab, M.; Fatima, M.; Abbas, S.; Sharif, Y.; Umair, M.; Zafar, M.H.; Bahadar, K. Role of secondary metabolites in plant defense against pathogens. Microb. Pathog. 2018, 124, 198-202. [CrossRef] [PubMed]

52. Zozio, S.; Servent, A.; Cazal, G.; Mbéguié-A-Mbéguié, D.; Ravion, S.; Pallet, D.; Abel, H. Changes in antioxidant activity during the ripening of jujube (Ziziphus mauritiana Lamk). Food Chem. 2014, 150, 448-456. [CrossRef] [PubMed] 